OPEN ACCESS

Edited by:

Samuel Abiven,

University of Zurich, Switzerland

Reviewed by:

Jakob Zopfi,

University of Basel, Switzerland

Philippa Louise Ascough,

Scottish Universities Environmental

Research Centre, UK

*Correspondence:

Kirsten Küsel

kirsten.kuesel@uni-jena.de

Specialty section: This article was submitted to

Biogeoscience,

a section of the journal

Frontiers in Earth Science

Received: 16 November 2015 Accepted: 17 March 2016

Published: 26 April 2016

Citation:

Küsel K, Totsche KU, Trumbore SE, Lehmann R, Steinhäuser $C$ and Herrmann M (2016) How Deep Can

Surface Signals Be Traced in the Critical Zone? Merging Biodiversity with Biogeochemistry Research in a Central German Muschelkalk Landscape. Front. Earth Sci. 4:32. doi: 10.3389/feart.2016.00032

\section{How Deep Can Surface Signals Be Traced in the Critical Zone? Merging Biodiversity with Biogeochemistry Research in a Central German Muschelkalk Landscape}

\author{
Kirsten Küsel ${ }^{1,2 *}$, Kai U. Totsche ${ }^{3}$, Susan E. Trumbore ${ }^{4}$, Robert Lehmann ${ }^{3}$, \\ Christine Steinhäuser ${ }^{1}$ and Martina Herrmann ${ }^{1,2}$
}

\begin{abstract}
${ }^{1}$ Aquatic Geomicrobiology, Institute of Ecology, Friedrich Schiller University Jena, Jena, Germany, ${ }^{2}$ German Centre for Integrative Biodiversity Research (iDiv) Halle-Jena-Leipzig, Leipzig, Germany, ${ }^{3}$ Hydrogeology, Institute of Geosciences, Friedrich Schiller University Jena, Jena, Germany, ${ }^{4}$ Biogeochemical Processes, Max Planck Institute for Biogeochemistry, Jena, Germany
\end{abstract}

The Earth's Critical Zone $(\mathrm{CZ})$ is a thin living layer connecting atmosphere and geosphere, including aquifers. Humans live in the $\mathrm{CZ}$ and benefit from the vital supporting services it provides. However, the $\mathrm{CZ}$ is increasingly impacted by human activities including land and resource use, pollution, and climate change. Recent interest in uniting the many disciplines studying this complex domain has initiated an international network of research infrastructure platforms that allow access to the CZ in a range of geologic settings. In this paper a new such infrastructure platform associated with the Collaborative Research Center AquaDiva is described, that uniquely seeks to combine CZ research with detailed investigation of the functional biodiversity of the subsurface. Overall, AquaDiva aims to test hypotheses about how water connects surface conditions set by land cover and land management to the biota and biogeochemical functions in the subsurface. With long-term and continuous observations, hypotheses about how seasonal variations and extreme events at the surface impact subsurface processes, community structure and function are tested. AquaDiva has established the Hainich Critical Zone Exploratory (CZE) in central Germany in an alkaline geological setting of German Triassic Muschelkalk formations. The Hainich CZE includes specialized monitoring wells to access the vadose zone and two main groundwater complexes in limestone and marlstone parent materials along a $\sim 6 \mathrm{~km}$ transect spanning forest, pasture, and agricultural land uses. Initial results demonstrate fundamental differences in the biota and biogeochemistry of the two aquifer complexes that trace back to the land uses in their respective recharge areas. They also show the importance of antecedent conditions on the impact of precipitation events on responses in terms of groundwater dynamics, chemistry and ecology. Thus, we find signals of surface land use and events can be detected in the subsurface CZ. Future research will expand to a second CZE in contrasting siliciclastic parent rock, to evaluate the relative importance of parent material lithology vs. surface conditions for the emergent characteristics of the subsurface $\mathrm{CZ}$ 
and biodiversity. The Hainich CZE is open to researchers who bring new questions that the research platform can help answer.

Keywords: critical zone, microbial ecology, biogeochemical element fluxes, hydrogeochemistry, metabolomics, ecosystem disturbances, events, data mining

\section{INTRODUCTION}

The term "Critical Zone" (CZ) arose about a decade ago as part of a workshop that sought to bring together scientists studying weathering, hydrology, and biogeochemistry near the Earth's land surface (Basic Research Opportunities in Earth Science, 2015). The CZ extends from the vegetation canopy, through the soils or pedosphere, into the unsaturated and saturated bedrock including aquifers (Figure 1). This zone is deemed "critical" because it supports activities essential to human life, supporting our built structures and food production systems, and providing a waste repository as well as supplying much of our drinking water. It also provides the living environments for the majority of terrestrial biological activity. As human demands on the environment continue to accelerate in the next decades, even more rapid changes in the $\mathrm{CZ}$ will require systematic observation to better manage future crop production, water quality, and other services (Richter and Mobley, 2009).

Biogeochemical interfaces (Totsche et al., 2010), such as those connecting rock, water, air, organic matter, and organisms, are important to the functioning of the $\mathrm{CZ}$ across a range of spatial and temporal scales. These interfaces are organized in a complex, dynamic, and hierarchical system (Young and Crawford, 2004; Totsche et al., 2010) and can be conceived as a "biogeochemical reactor" that transforms the water, gases and other materials that pass through it. To understand the workings of this "biogeochemical reactor" requires a large transdisciplinary team bringing together knowledge of the geologic setting, flow of water and gases, transport of solutes and colloids, chemical transformations through weathering, sorption, or precipitation/dissolution, and the tools to determine the diversity of its resident organisms and the function of its communities. To do so in a comprehensive manner, Critical Zone observatories (CZOs) have been established over the last 8 years in a number of countries ${ }^{1}$. One major goal of CZOs is to provide the physical infrastructure required to access and investigate the entire zone of complex interactions involving rock, soil, water, air, and living organisms that regulate the natural habitat of the CZ (Basic Research Opportunities in Earth Science, 2015). Such coordinated research platforms and data systems in turn bring together researchers from a wide range of disciplines and provide a library of information for synthesis and hypothesis testing, both at a single $\mathrm{CZO}$ and by comparing sites that differ in factors like lithology or climate.

Many of the existing CZOs (Figure 2) originated with a focus on understanding regolith formation and weathering. However, despite the clear importance of organisms to the

Abbreviations: Hainich Transect Upper Aquifer Assemblage, Lower Aquifer Assemblage (HTU, HTL)

${ }^{1}$ http://www.czen.org weathering process, the investigation of the diversity of life inhabiting and interacting with these CZOs has received less emphasis to date. This is especially true for the zone below the majority of plant roots and extending into the aquifers assemblages used locally for drinking water and geothermal applications, here defined as the subsurface (Figure 1). Resulting, to some extent, from a decreasing availability of mineralizable organic carbon, microbial abundance, diversity, and activity in the vadose zone are lower than in surface soils but may increase again within the capillary fringe and the groundwater zone. (Holden and Fierer, 2005) Nevertheless, living microorganisms involved in the reduction of nitrate, sulfate and iron as well as acetogenesis, and methanogenesis have been reported from groundwater within granitic bedrock at depths of up to 978 m (Pedersen, 1997; Hallbeck and Pedersen, 2008) while the maximum depth of terrestrial subsurface drilling from which living organisms have been reported is $5.3 \mathrm{~km}$ (Szewzyk et al., 1994). Progress will require not just a cataloging of subsurface life, but an understanding of how the biodiversity of the subsurface transforms the mineralogy, shapes its physical and

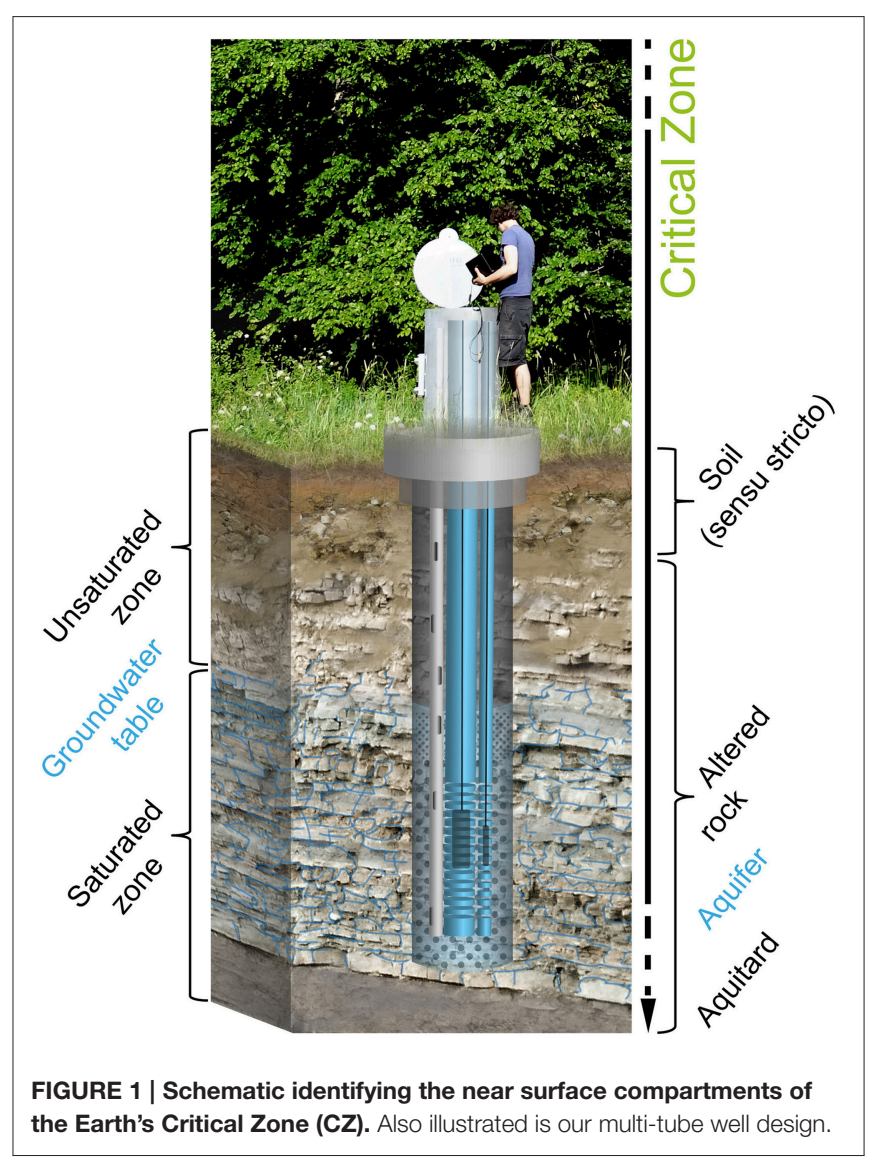




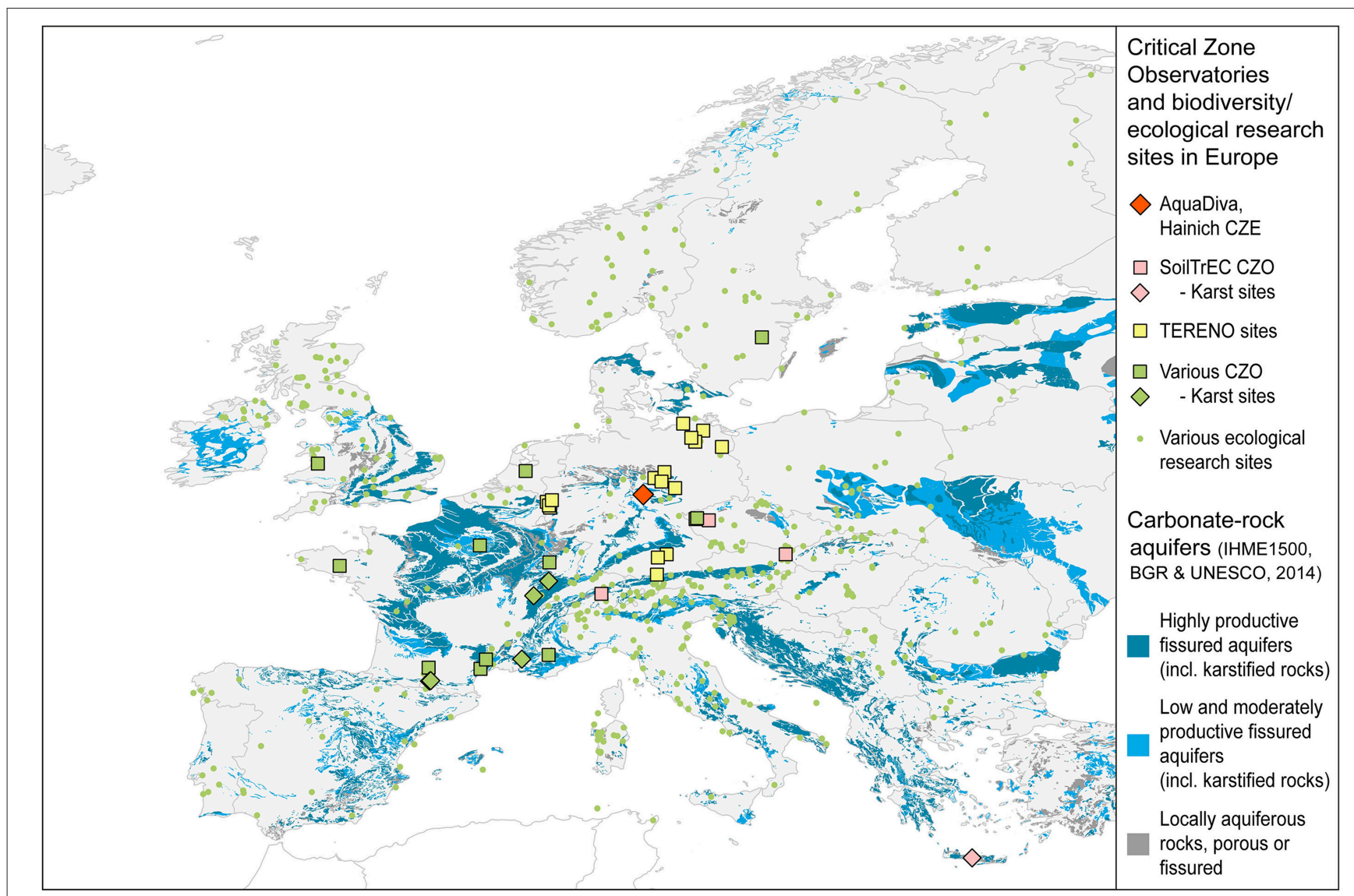

FIGURE 2 | Distribution and classification of carbonate-rock aquifers in Europe. European CZOs (squares) and biodiversity study sites (green dots) are mainly placed in non-carbonate geological settings or focus on the vegetation and shallow surface/soil biodiversity. Data Sources: BGR and UNESCO. (2014; aquifer distribution, aquifer classification), BGR (2005; base map). Research site locations: DEIMS $(2015)^{2}$, RBV $(2015)^{3}$, SoilTrEC (2015) ${ }^{4}$, TERENO (2015) ${ }^{5}$.

trophic environment, and influences the gases, water, solutes, and colloids moving through the CZ. Thus, we need to know not just who is there, but what they are doing to understand feedback mechanisms that determine the properties of the subsurface bioreactor, and their consequences for the range of services provided by the CZ.

Functional biodiversity-the discovery of relationships between the diversity of life and ecosystem functioning-is one of the most dynamic areas in contemporary ecology research. The concept of "diversity" extends beyond the number and characteristics of plant and animal species (found mostly at the $\mathrm{CZ}$ surface) to encompass the diversity of genes, the diversity of chemical constituents, the diversity of functions and actions of organisms and interactions between organisms and finally the diversity of structure and function of ecosystems (Loreau et al., 2002). In this context, a number of field scale experiments have been established over the past decades. For example, one study demonstrated the importance of fungal and microbial

\footnotetext{
${ }^{2}$ https://data.lter-europe.net/deims

${ }^{3}$ http://rnbv.ipgp.fr/?page_id $=62$

${ }^{4}$ http://www.soiltrec.eu/CZOPages/wfieldSites.html

${ }^{5}$ http://teodoor.icg.kfa-juelich.de/observatories
}

turnover of plant-derived carbon for fueling the food web in agricultural soils (Kramer et al., 2012). This experiment also showed that bacteria originating in the rhizosphere can be translocated from topsoil to subsoil and beyond with snowmelt, demonstrating the role of weather events for the translocation of biota to the deeper subsurface (Dibbern et al., 2014). Experiments that manipulate plant species diversity have been used to investigate its role in soil ecology and biogeochemistry, as well as promoting stability given external change (e.g., Proulx and Fahrig, 2010). As the duration of these experiments increases, so does our knowledge of these measurable effects of plant diversity on soil organisms (Eisenhauer et al., 2011) and functions like soil organic matter storage (Lange et al., 2015). In fact, plant diversity effects can be even more important for the structure and functioning of soil food webs than changes in atmospheric $\mathrm{CO}_{2}$ concentrations or nitrogen deposition (Eisenhauer et al., 2013). However, these studies rarely extend beyond the depth where the majority of plant roots are-i.e., the A horizons, generally the upper $20-30 \mathrm{~cm}$ of soil.

Few such studies pay much attention to the role of the geologic setting of the experiment. Thus, especially when extending into the subsurface CZ, a major question is the relative importance 
of parent rock material vs. surface biota on the diversity and function of the subsurface, and how the characteristics of the subsurface might influence surface biodiversity and geomorphology. The geologic setting controls the subsurface in a number of fundamental ways-by setting the overall patterns of fluid flow (e.g., hydraulic structure), the spatial and temporal distribution of possible sources of energy from transported dissolved organic carbon (DOC) or reduced gases (e.g., $\mathrm{CH}_{4}$, $\mathrm{H}_{2}$ ), the rates of physical vs. chemical weathering and the chemistry of weathering itself, and the $\mathrm{pH}$, which is a main driver structuring microbial communities and their metabolism. Although all of these factors impact the architecture and function of the subsurface, major questions are so far unanswered and still under scientific debate: What are the relative importance of the geologic setting and surface characteristics in controlling the functional biodiversity of the subsurface? To what depth does the influence of surface diversity extend? What are the processes that couple subsurface to surface and how are they impacted by human activities?

Although we have only little general knowledge of the inhabitants of the subsurface, mostly from aquifers (e.g., Goldscheider et al., 2006; Amalfitano et al., 2014) or karst conduits and caves (Brigmon et al., 1994; Farnleitner et al., 2005; Pronk et al., 2008), they are increasingly subject to human impacts. These include direct impacts through activities like heat and energy exchange, structure-altering resource extraction, and use for waste disposal or gas storage. Less easily seen, but perhaps no less important, are indirect impacts through the downward communication of changes in properties of the atmosphere, vegetation, and topsoil. Again, a major question is the degree to which the geologic setting interacts with human impacts such as land use change that occur at the surface. In other words, will the same change in surface conditions produce the same subsurface response in a different geologic setting?

\section{THE AQUADIVA APPROACH}

In this paper, we describe the Hainich Critical Zone Exploratory (Hainich CZE) in central Germany (Figure 3), an infrastructure designed specifically to investigate the role of biota in shaping the subsurface compartments of the CZ. We also use initial results to demonstrate that surface conditions indeed influence the subsurface functional diversity and groundwater chemistry, and show that extreme precipitation events have a complex effect on subsurface conditions. Various hypotheses about how water connects surface and subsurface, detailed below, can now be explored.

The Hainich CZE, already implemented within the framework of the "ProExzellenz" initiative AquaDiv@Jena (2009-2012, Contract No 107-1) funded by the state of Thuringia, and fully established within the collaborative research centre (CRC) AquaDiva ${ }^{6}$ funded by the Deutsche Forschungsgemeinschaft (German Research Foundation, DFG), is unique in its emphasis on applying modern molecular, "omic" and computational tools useful for exploring the identity and metabolism of organisms

${ }^{6} \mathrm{http}: / /$ www.aquadiva.uni-jena.de inhabiting the $\mathrm{CZ}$ and exploring their role in setting emergent properties of the $\mathrm{CZ}$ biogeochemical reactor.

In establishing AquaDiva's CZE at Hainich, we aimed for a holistic description of the subsurface $\mathrm{CZ}$ in a region with a range of land use characteristics. There are three major components of investigation: (i) identifying a variety of surface-or subsurfacespecific patterns (e.g., of water infiltration, solutes, colloids) and signals (e.g., biomarkers, specific organisms; for example the presence or absence of specific fungi) and attempting to trace these into the various compartments of the subsurface; (ii) characterizing the biota that live in the subsurface and identifying their energy source and metabolism; and (iii) combining studies of flow and transport within the subsurface with biological and chemical characteristics to understand the influence of the surface on the subsurface in general, and how that is shaped by singular events.

The Hainich CZE was built in a landscape formed from sedimentary carbonate rocks with young groundwaters in partly karstified aquifers (Figure 2). Carbonate rocks cover over 20\% of the Earth's ice-free continental area and karst aquifers represent important drinking water reservoirs, supplying up to $25 \%$ of the world's population with fresh water (Ford and Williams, 2015). Previous investigations of the microbial inventory of karst aquifers primarily focused on spring water or caves that allow easier access, pointing to the presence of autochthonous microbial endokarst communities but also to high temporal dynamics, indicated by the episodic occurrence of allochthonous soil bacteria within the spring water communities (Farnleitner et al., 2005; Pronk et al., 2008; Shabarova et al., 2013). However, less information is available for groundwater obtained from drilled boreholes within a karstic limestone setting (Gray and Engel, 2013). Studies of carbon cycling in kart environments have often focused on using isotopes to quantify the dissolution and precipitation of carbonates (models reviewed in Han and Plummer, 2013) or to understand the degree to which C derived in soils can be recorded in cave deposition (Noronha et al., 2014). The Hainich CZE is one of just a few observatories located in this important lithology. In the upcoming years we will establish a second CZE in a contrasting, siliciclastic geologic setting within the Thuringian Basin, to generally address the overall research question of AquaDiva.

\section{HOW DO SURFACE CONDITIONS, LIKE LAND USE AND EVENTS, AND LOCAL GEOLOGY SET THE FUNCTIONAL BIODIVERSITY OF THE SUBSURFACE?}

By combining approaches and methods from a range of complementary disciplines, we seek to understand and quantify the functioning of the subsurface, its biodiversity and how those depend on the local geologic conditions, surface vegetation and land use.

Two main hypotheses underlie the design of the infrastructure we will use to answer our research question. The first is that the surface and subsurface are coupled by fluid flow-in other words, that changes such as land cover or land use at 


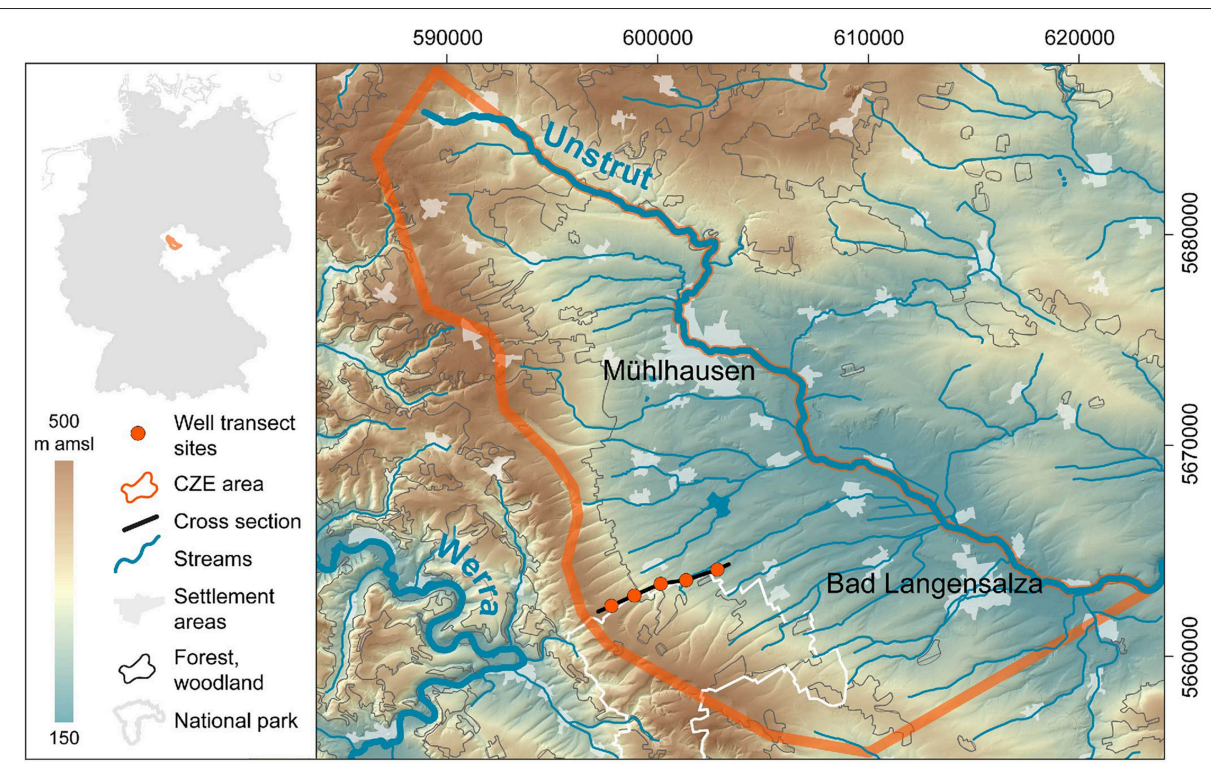

FIGURE 3 | Location of the Hainich CZE in a topographic map of northwestern Thuringia/Germany. Data Sources: DEM ๑GeoBasisDE/TLVermGeo, Gen.-Nr.:12/2015; DLM250 (c) GeoBasis-DE/BKG 2014: Coordinate system ETRS89/UTM, zone 32N.

the surface will propagate into the subsurface bioreactor and change the way it functions. How fast these signals propogate, and how far, will depend on surface properties and geologic setting. This concept is illustrated in Figure 4. The "null" hypothesis would be that the properties of the subsurface bioreactor are totally disconnected from surface conditions. To test the degree of coupling, we will identify "signals" of surface conditions and assess the degree to which these can be tracked downward and be reflected in the organization, diversity and function of the subsurface community dominated by microbial life. Currently the "signals" we use include biomarker molecules, and their isotopic signatures (e.g., radiocarbon content reflecting ancient or recently photosynthetically fixed C), specific kinds of colloids, organisms, or combinations of nutrient or tracer distributions that indicate underlying stoichiometry. As illustrated conceptually in Figure 4, these signals can be altered or transformed as they are transported through the $\mathrm{CZ}$, and/or diluted by other signals of processes operating in the subsurface. For example, we seek to discover to what degree dissolved or particulate organic matter (DOC/POC) in the subsurface show similarities on a molecular basis to the original plantderived compounds, or reflect vegetation-derived $\mathrm{C}$ that has been microbially recycled and transported downward with seepage waters. The challenge is thus to observe the degree to which signals in the subsurface provide a recognizable suite of clues that reflect the changing nature of the surface vegetation.

Part of demonstrating that surface influences subsurface, involves elucidation of the mechanisms that are operating. In particular research related with the assessment of the vulnerability of aquifers have broadened our knowledge on the substances and processes that threaten groundwater resources (e.g., Zwahlen, 2004; Andreo et al., 2009; Vias et al., 2010). Flows of water and gas provide the transport link between surface and subsurface. For example, it is well-known that large structural pores or macropores play a role in nonequilibrium water flow and solute, colloidal, and particulate transport, that moves either organic contaminants to aquifers forming plume compartments (Totsche et al., 2007; Winderl et al., 2008), or trace metals, nitrate and phosphorous, pesticides and antibiotics from agricultural soils into groundwater (Jarvis, 2007). Surface vegetation may influence these exchanges, however. Tracer experiments show that stemflow routed along biopores contributes disproportionately to groundwater recharge and is therefore a shortcut from the surface to depth (Taniguchi et al., 1996). Even the structure of a forest canopy can provide preferred pathways for water by focusing dripping, and therefore enhance water input in spatially heterogeneous ways (Stan et al., 2015). The inputs of chemical constituents also depend on preferred pathways. For example, experiments with isotopelabeled litter make it clear that macropore flow provides direct input of surface-derived dissolved organic carbon (DOC) below the main rooting zone in forests (Froberg et al., 2007; Winderl et al., 2008) or even down to the aquifers (e.g., Perrette et al., 2015).

A special area of emphasis in our research is the tracing of organic matter through the $\mathrm{CZ}$. The reduced $\mathrm{C}$ in organic matter provides the energy "currency" for heterotrophic metabolism. The mineralization of dead organic matter and the formation and stabilization of soil organic matter is one of the most important ecosystem services provided by soil biota, with consequences for soil fertility, plant growth, soil structure, carbon sequestration, and for water holding capacity and hydraulic conductance. Decomposition also alters the concentrations of electron acceptors and releases nutrients to solution, which in turn influence $\mathrm{pH}$, redox conditions and the structure of microbial communities. Thus, the identification of primary 


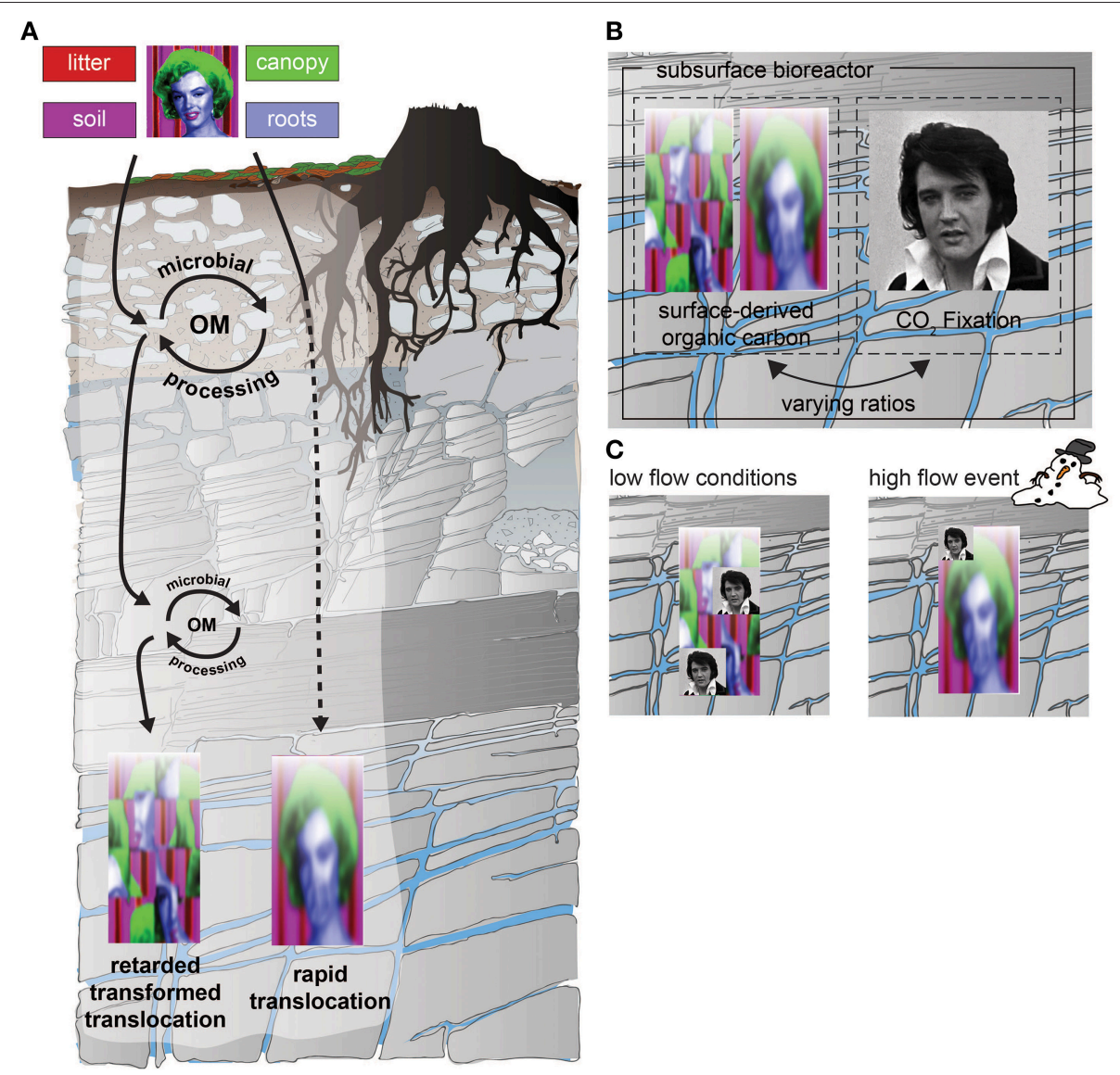

FIGURE 4 | (A) Potential transformations of signals (components of Marylin) originating at the surface and moving through the subsurface CZ. Signals include individual biomarker molecules or collections of compounds, colloids or even organisms specific to surface origin or indicative of surface processes. These are transported down through the CZ by water, but can be transformed by incorporation into subsurface biota or diluted by other signals. (B) The subsurface CZ is not just a zone through which materials move and are filtered/transformed, it is also the habitat for chemolithautotrophs (represented here by Elvis) that can add completely new signals, or patterns of nutrient/energy use. (C) The degree to which these signals travel in the subsurface CZ depends on the relative rates of input, but also on the flow (connection) between zones. For example, under low flow conditions ( $0.2 \mathrm{~mm} /$ day), where the subsurface CZ is more disconnected (left), the in situ biota may have the strongest imprint, while during high flow events ( $20 \mathrm{~mm} /$ day), the in situ signals may be diluted by the increased transport of filtered signals from the surface.

organic matter, as well as the transformations, transport and fate of organic matter, and the products of decomposition/recycling (organisms, particles, colloids, dissolved, and gaseous forms of carbon) are important for understanding how energy and matter are delivered to the subsurface. The literature has emphasized our lack of understanding of organic matter cycling in the subsurface, especially in non-contaminated settings, and suggests that it may be more dynamic than previously thought (Trumbore et al., 1995; Richter et al., 1999; Kracht and Gleixner, 2000; Baisden et al., 2002a,b; Prokushkin et al., 2007; Steinbeiss et al., 2008; Kindler et al., 2011). By using both ${ }^{13} \mathrm{C}$ and ${ }^{14} \mathrm{C}$ carbon isotopes in the karst setting of the Hainch CZE we will be able to trace $\mathrm{C}$ atoms through the foodweb (Kramer et al., 2012) and the various organic matter pools transiting the $\mathrm{CZ}$-for example using radiocarbon signatures to distinguish $\mathrm{C}$ recently fixed from the atmosphere from more ancient $\mathrm{C}$ sources, and ${ }^{13} \mathrm{C}$ to distinguish plant-derived from inorganic $\mathrm{C}$ sources (Gillon et al., 2009, 2012).
In addition to filtering and altering the signals originating at the surface, biota inhabiting the $\mathrm{CZ}$ also contribute their own unique signals, including $\mathrm{C}$ sources (Figure 4A). Traditionally it has been assumed that subsurface microbial processes are dependent on reduced $\mathrm{C}$ originating from photosynthesis (represented by "Marilyn" in Figure 4A). Hence the surface would necessarily dictate subsurface characteristics (Culver et al., 1985; Baker et al., 2000; Foulquier et al., 2010; Akob and Küsel, 2011; Foulquier et al., 2011; Pan et al., 2014; Figure 4A). However, reduced carbon can also enter soils via microbial non-photoautotrophic $\mathrm{CO}_{2}$ fixation (represented by "Elvis" in Figure 4B) and this carbon can be important to soil microenvironments despite its relatively small contribution to fixed C (0.05\% of soil organic carbon; Miltner et al., 2004, 2005). Thus, chemolithoautotrophy catalyzed by Bacteria and Archaea is another possible source of organic carbon and can impart unique signals to the subsurface (Figure 4B). A major goal of AquaDiva is thus to quantify the relative roles of transport vs. 
chemolithoautotrophy as sources of reduced C in the subsurface, the factors that regulate this balance, and the consequences for the subsurface environment.

There is evidence for microbial activity even in deep continental fractures and aquifers, and conservative assumptions suggest a deep continental biomass of $10^{16}-10^{17} \mathrm{~g} \mathrm{C}$, or $2-19 \%$ of Earth's total biomass (McMahon and Parnell, 2014). Life can be sustained in the subsurface in the absence of oxygen due to the availability of alternative electron acceptors, e.g., metals, sulfur, etc., that have accumulated from rock weathering (McCollom and Seewald, 2013). Geological processes transporting chemical energy in the form of gases, such as hydrogen $\left(\mathrm{H}_{2}\right)$, methane $\left(\mathrm{CH}_{4}\right)$, or reduced metal ions can support rich and diverse microbial communities near hydrothermal vents (Hinrichs et al., 1999; Boetius et al., 2000; Michaelis et al., 2002). Explorations of saline fracture waters in the deep Precambrian shields also identified subsurface environments rich in $\mathrm{H}_{2}$ similar to those found at hydrothermal vents (Sherwood Lollar et al., 2007). Alkaline saline groundwaters found at 2.8 kilometers depth in Archaean metabasalt are dominated by thermophilic sulfate reducers that appear to be sustained by geologically produced $\mathrm{H}_{2}$ and sulfate at concentrations sufficient to maintain activities for millions of years with no reliance on photosynthetically derived substrates (Lin et al., 2006).

Most subsurface microorganisms-even those living closer to the surface than the very deep biosphere examples discussed above-can live in conditions of extreme energy limitation, with generation times of months or even hundreds of years which is not comparable to the knowledge we gained from studying laboratory cultures (Jorgensen and Boetius, 2007; D'Hondt, 2013). The energy available might only be sufficient to maintain cell processes exclusive of biomass production without the input of fresh organic matter (Hoehler and Jorgensen, 2013). Thus, we have to determine how microorganisms have adapted to potentially oligotrophic conditions in the subsurface and which metabolic processes are operating, especially the balance of autotrophic and heterotrophic pathways.

There is increasing evidence of an important role of lithoautotrophy for carbon flow, especially in aquifers (Pedersen and Ekendahl, 1992a,b; Alfreider et al., 2003; Alfreider and Vogt, 2012; Kellermann et al., 2012). Recent studies suggest that microbial $\mathrm{CO}_{2}$ assimilation in aquifers could be fuelled by energy conserved by nitrification, oxidation of ferrous iron and reduced sulfur compounds (Alfreider et al., 2003; Alfreider and Vogt, 2012), or from the oxidation of $\mathrm{H}_{2}$ or $\mathrm{CH}_{4}$ (Tiago and Verissimo, 2013). We will infer the importance of autotrophic processes from the presence and activity of lithoautotrophs by targeting and quantifying functional genes specific for different autotrophic pathways, in addition to measuring rates of $\mathrm{CO}_{2}$ fixation and inferring metabolic changes from evolving chemistry and isotopic signatures of gases and groundwaters (i.e., to quantify the relative influence of Marilyn (surface) and Elvis (in situ chemolithoauthotrophy) on the signals we observe the subsurface). Biomass derived from chemolithoautotrophy could consistently fuel subsurface food webs, since this autochthonous resource is largely decoupled from surface processes. We seek to disentangle the activity in such food webs from the actual source of $\mathrm{C}$ atoms-which could be recycled multiple times between organic and inorganic forms.

\section{THE IMPORTANCE OF SINGULAR AND EXTREME EVENTS}

The second hypothesis underlying our measurement approach is that the connection between surface and subsurface will vary over time, e.g., with season or with extreme events. Surface and subsurface are connected by a zone of variable moisture content (the "unsaturated" and saturated zones; Figure 1). Hydraulic short-circuiting between these compartments occurs in recharge regions and along macropores, and during events such as snowmelt and heavy rains (Praamsma et al., 2009; Schiperski et al., 2015). Such events may also dominate the transfer of energy and matter through the subsurface and determine the degree of connection with the surface. Events may alter system inputs, especially the allochthonous resource supply, as well as the rate and efficiency of transport of water, colloids and microorganisms into the subsurface. Thus, one goal of AquaDiva is to investigate the role of such events on the subsurface bioreactor by monitoring changes in inputs, community structure, internal transformation, and exports on timescales sufficient to resolve events and their effects (Figure 4B).

One important issue is the degree to which periodic or eventdriven delivery of nutrients and energy to aquifers sustains the subsurface biota. As illustrated in Figure 4C, we hypothesize that under low flow conditions, the signals from autotrophic pathways in the subsurface may be more important, while those from the surface become less recognizable as they are processed and recycled over time. In high flow events, we hypothesize that surface signals may dominate because bypass flow delivers more reduced $\mathrm{C}$ and increases the ratio of heterotrophy to autotrophy in the subsurface. Such events provide not only energy source, but also additional nutrients and even biota that can temporarily alter biogeochemical cycles in the subsurface. The importance of events to sustain biodiversity and function in the subsurface is of particular importance for understanding how climate change or associated disturbances may affect $\mathrm{CZ}$ processes, since a major effect of climate change will be an increase in extreme events. ${ }^{7}$

Events are not restricted to anomalous water inputs alone. For example, herbivorous insect infestations have been shown to significantly alter DOC fluxes in throughfall and thereby affect element and nutrient cycling in forests (Stadler and Michalzik, 2000). Herbivore defoliation will also increase the throughfall inputs of total and dissolved organic $\mathrm{C}$ and $\mathrm{N}$ to the forest floor (le Mellec and Michalzik, 2008; Michalzik, 2011). Extreme droughts and fires are another kind of disturbance that can add organic $\mathrm{C}$ with unique properties to the surface, and research is needed on the fate of charred materials in landscapes. Windthrow events can cause significant structural changes in soils, as well as increasing surface inputs. In non-forest land uses, events include management activities such as ploughing,

\footnotetext{
${ }^{7}$ http://www.ipcc.ch/publications_and_data/publications_ipcc_fourth_assessment
} _report_wg1_report_the_physical_science_basis.htm 
mowing or fertilization impact on surface and soil structure and properties. Much more still remains to be learned and evaluated. Comparing the impact of climatic and other events on the subsurface requires continuous observation of temporal variations in the properties of the subsurface environment and changes in the metabolic functions of the subsurface biota. In the initial stages of AquaDiva we put particular emphasis on seasonal changes (snowmelt), singular abiotic and biotic events, and inter annual variations in the environmental conditions given by $\mathrm{pH}$, electrical conductivity, dissolved and colloidal organic matter concentration, redox potential, dissolved oxygen, temperature concentration, ant the composition of major cations, and ions. These observations can be used to test models that couple surface infiltration and water balance with subsurface hydrologic flows and ultimately improve predictions of the magnitude and frequency of floods in response to extremes (Kumar et al., 2010).

\section{THE HAINICH CZE: AN INTRODUCTION TO THE AQUADIVA RESEARCH INFRASTRUCTURE}

The Hainich CZE is located at the western margin of the Thuringian Basin (Figure 3), a medium sized sedimentary basin in central Germany. The CZE with a areal size of $430 \mathrm{~km}^{2}$ covers the northeastern slope of the Hainich low mountain range, including the recharge areas of the target aquifers, the distribution areas of related geological units, tributaries and the main discharge or the Unstrut river, which drains this subcatchment to the Saale, the tributary river to the Elbe, that finally discharges into the North Sea. The CZE comprises an observational transect (Figure 5) spanning different land management systems with a series of instrumented soil monitoring plots and groundwater wells that provide access to the hidden subsurface compartments of the CZ. Vertically the observatory reaches from treetops down to $90 \mathrm{~m}$ in the subsurface at the deepest point.

The transect marks roughly the northern border of the Hainich national park, which hosts parts of the monitoring areas of the German Biodiversity Exploratories ${ }^{8}$, where several long term measurements, including eddy covariance measurements of energy, water and C fluxes take place (Knohl et al., 2003). Mean annual temperatures vary between 7.5 and $8.0^{\circ} \mathrm{C}$ (Hainich ridge, top of the transect) and $9.0-9.5^{\circ} \mathrm{C}$ (Unstrut valley, Bad Langensalza). Mean annual precipitation varies between 900 and $1000 \mathrm{~mm}$ (Hainich ridge) and $<600 \mathrm{~mm}$ (Unstrut valley) with the predominance of precipitation falling in the winter season ${ }^{9}$. Major land uses are unmanaged woodland (primeval beech forest, national park), managed forest (Hainich low mountain range top and upper slopes) and a mosaic of pasture and agriculture (footslopes, valley bottom). A number of small villages (Kammerforst, Langula, Flarchheim) are located at the footslopes.

\footnotetext{
${ }^{8} \mathrm{http}: / /$ www.biodiversity-exploratories.de

${ }^{9}$ http://www.tlug-jena.de/uw_raum/umweltregional/uh/uh09.html
}

The CZE with its well- and plot- transect (Figure 5) is mainly underlain by rocks of the Middle Triassic epoch. The land surface developed from layers of Upper Muschelkalk at the mountain ridge and slopes and on sediments of Lower Keuper in the eastern, footslope/plane parts but also on overlying deposits of Pleistocene Loess and Holocene unconsolidated alluvium. The soils found are typical for the pedogenesis in parent materials from limestone, dolomite and marlstone (e.g., Regosol, Rendzina, Terra fusca), and loess (e.g., Fluvisols and planosols) with colluviums found at footslope positions and depressions.

The groundwater aquifers targeted within AquaDiva's Hainich CZE are those of the Upper Muschelkalk subgroup. Ongoing tectonic activity in the basin results in a number of fault zones that control regional surface and subsurface water flow. The investigated aquifers developed in solid carbonate rock due to tectonic stress (fracturing) and weathering. The major lithologies of the Upper Muschelkalk include alternated stratification of limestones and marlstones. Subrosion and karstification of underlying sulfates (Middle Muschelkalk) led to hanging wall collapse and the formation of karst features like sinkholes. To simplify this complex picture, we distinguish two main aquifer assemblages in the lithostratigraphic formations of the Upper Muschelkalk: the main and "lower" aquifer(s) in the Trochitenkalk formation (moTK) and "upper" and minor aquifers within the Meissner (moM) and Warburg (moW) formation (summarized to "Ceratites Beds," $m o C$, in regional lithostratigraphic nomenclature), both contain within limestone beds. The fractured aquifer system within $m o C$ is characterized by joints, and dissolution pores, while the lower moTK shows more intensive karstification, by widened fractures up to expected large conduits allowing for fast flow and transport processes. The two assemblages are largely distinct from one another. They are separated by intercalated dense and sealing marls and lesser permeable marly limestones of variably thickness that serve as aquitards.

The Hainich Transect Upper Aquifer Assemblage (HTU, moC aquifers) is partly present in the Hainich ridge top and midstream wells, with recharge areas outcropping in all land use types. The Lower Aquifer Assemblage (HTL, moTK aquifers) spans the whole transect. Due to the dipping strata and aquitards comprising overburden, the HTL's recharge areas are mainly in the uphill parts of the transect and Hainich ridge. Here, the signal and matter input to the groundwater will be dominated by the forest, while in the downhill area, the signals and inputs of grassland and agriculture might add to the composition and properties of the groundwater by enhanced flowpaths like karst input features. The short distance from the surface to the aquifer at $\mathrm{H} 1$ (less than $2 \mathrm{~m}$ ) might allow us to identify signals derived from the forest and to trace these signals in the groundwater flow down to the other sites (with a maximum of $90 \mathrm{~m} \mathrm{depth}$ ). This situation provides a unique basis to explore the distance over which coupling between surface and subsurface can be traced. Moreover, as the aquifers are affected by different land uses, it will be possible-provided specific signals or markers are identified-to discern land use effects for conveying surface and soil signals into the deeper subsurface compartment of the CZ. 


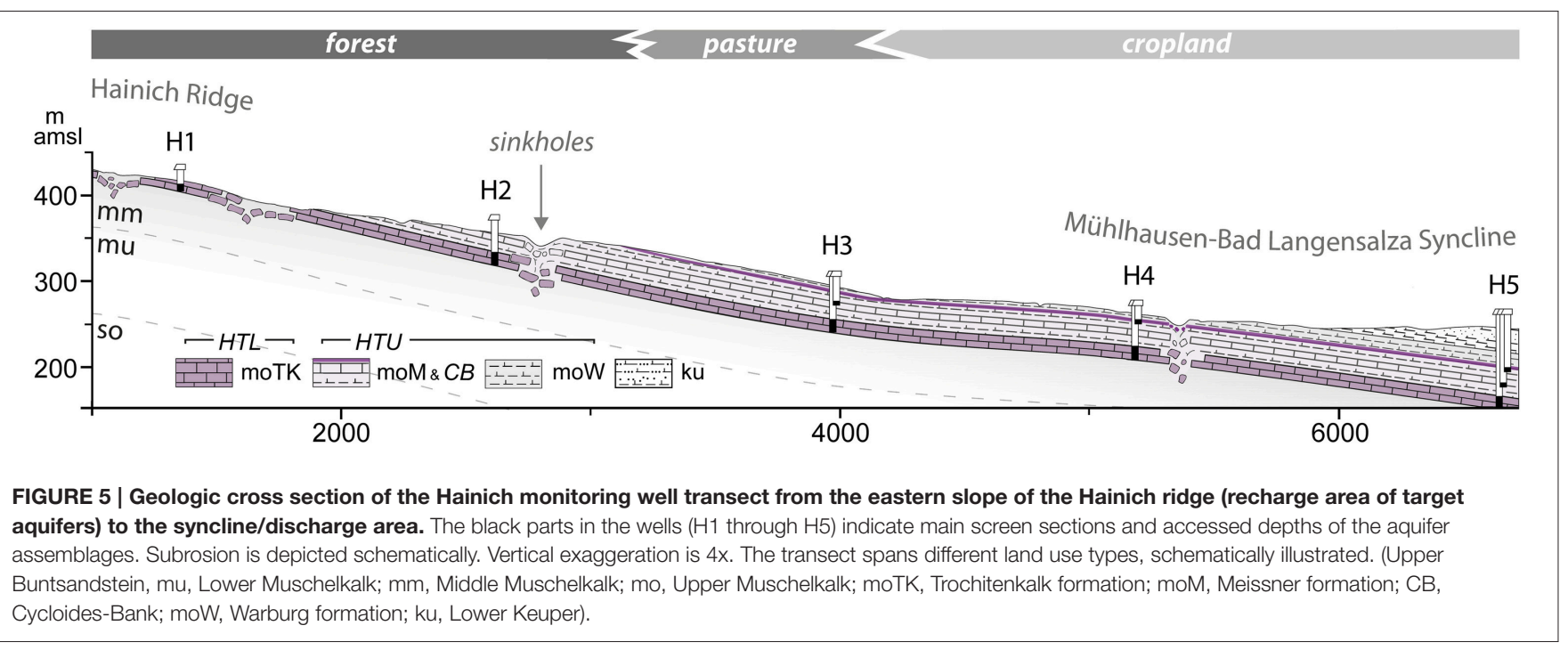

\section{BUILDING THE TRANSECT: WELL DESIGN AND INSTRUMENTATION}

Initially, a series of liner core drillings were performed for rock sampling and probing. Then a transect of groundwater wells were installed along the topographical gradient, longitudinal to the major groundwater flow direction, to grant access to the two major aquifer assemblages (as illustrated in Figure 5). The well transect spans the land use change typical for the region, with deciduous managed forest (location H1) or unmanaged woodland (H2) on the hilltop (western part), grassland/pasture (H3) to cropland agriculture (H4, H5, eastern part) over a distance of $\sim 6 \mathrm{~km}$. In the vertical direction, the well transect cuts into formations of the Upper Muschelkalk (H1-H5) and Lower Keuper (top of H5) and grants access to a major groundwater complex that is built of two superimposed and partially disjoint aquifer systems: HTU, whose top ranges from some tens of centimeters below surface with only a thin soil cover $(\sim 0.6 \mathrm{~m})$ to approximately 30 meters below surface with thicker soils $(\sim 1.5 \mathrm{~m})$ and Keuper sediments as overburden. $\mathrm{HTL}$, whose top ranges from centimeters to $\sim 2 \mathrm{~m}$ at $\mathrm{H} 1$ with variable soil thickness (up to $2 \mathrm{~m}$ ) to a depth of 85 meters at $\mathrm{H} 5$.

In order to facilitate sampling of biota and colloidal materials, a novel multi-tube well design (Figure 6) was developed. To allow for collection of even higher order groundwater dwelling biota like arthropods (crustacean) we utilized coarse slotted well screens and coarse filter packs (glass beads up to a mean diameter of $21 \mathrm{~mm}$, Figure 6F) in the main screen sections to provide minimum reactive surface and minimize attachment and/or sorption to the filter material. This also provides large pores to allow suspended particles including organisms up to the size of a few millimeters to enter the groundwater wells. As the limestone environment is prone to karst development, short circuiting and communication in between the different aquifers is likely to occur. Thus, we decided against multi-level wells in favor of single aquifer wells. As a consequence, each target aquifer is equipped with a single and isolated groundwater observation well.

To preclude contamination of well waters by vertical mixing, we drilled clusters of single wells, each of which has a single screen depth (i.e., each well samples one depth interval). The whole equipment was rinsed with alcohol, water and flushed with the formation water from target aquifers prior deployment. Each of these wells is equipped with up to three individual well tubes (Figures 6D-E). The central well tube (6 inch 6"; Figure 6C) is used for high-volume groundwater sampling and for the deployment of passive samples (Figure 6B). The passive samplers enable us to estimate weathering and mineral formation rates as well as the identification of attached biota after several months of deployment. Microbial partitioning between suspended populations and microbial populations attached to the surface of aquifer bedrock or sediment can have a considerable impact on the solute transport in aquifers due to differences in communities isolated show different carbon source utilization patterns (Lehman et al., 2001). To target these attached microbial communities we also analyzed the rock cores obtained during the drilling process of our wells and constructed bioreactors with original groundwater and rocks under controlled conditions in a climate chamber. Here, exposed rock material can be harvested in short time intervals to follow its colonization by indigenous microbial communities over time.

The second well tube ( $2^{\prime \prime}$ diameter; Figure 6D) hosts well loggers for pressure and temperature and multi-parameter loggers to monitor $\mathrm{pH}$, oxidation-reduction potential, specific electrical conductivity, dissolved oxygen and temperature in situ. The third tube (Figure 6E) is divided into multiple channels that allow for the depth resolved sampling of gases and water in the unsaturated zone and minor aquifers. Groundwater samples are taken monthly and measured for standard hydrogeochemical data and analysis of microbial communities (Table 1). In addition, every 3 months, high volumes (greater than 1000 liters) are filtered for analysis of DOM chemistry, biomarkers and compounds of microbial metabolism. Comparative pattern 


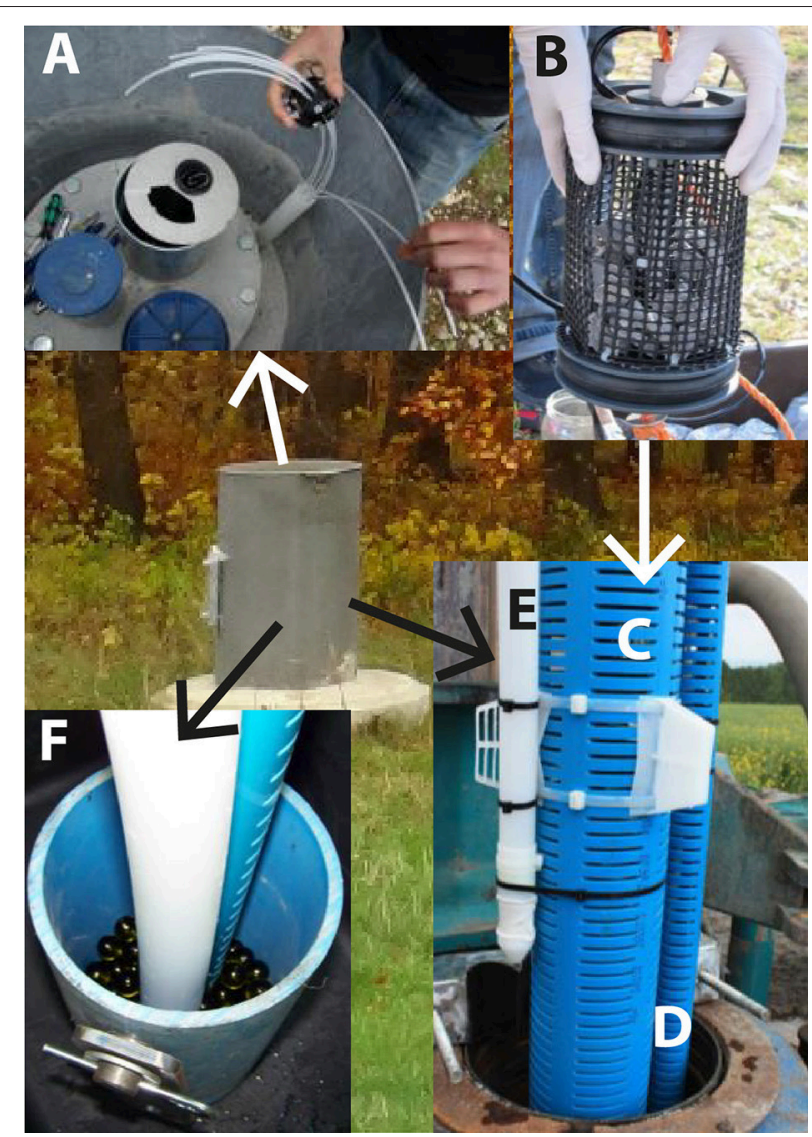

FIGURE 6 | Unique construction of ground water wells in the Hainich transect. Center: aboveground well structure. (A) View from the top with open well. (B) passive samplers that are filled with rock material suspended in groundwater to study attached organisms (C) Main screenpipe (6 inch 6") for groundwater sampling and installation of passive samplers (D) Secondary screenpipe ( 2 " diameter) for permanent installation of $\mathrm{p}$-T dataloggers and in-line optical sensors. (E) multi-channel tube with up to seven access ports for gas phase sampling. (F) backfilling of well with glass beads as a chemically inert material.

analyses will provide insights how turnover of carbon, microbial community patterns, and their metabolism are connected, providing an answer to our first hypothesis.

\section{INVESTIGATIONS AND MONITORING PROGRAM}

Over the next years, AquaDiva will regularly monitor the ground water chemistry, colloids, and inhabiting organisms in the wells (Table 1). All project data will be stored, managed and made available through a dedicated dataportal within AquaDiva. Dataportal is based on BEXIS2 data management software ${ }^{10}$. Using heavily instrumented field sites surface and soil characteristics, water infiltration and fluxes into the subsurface within forest and grassland are currently under investigation,

\footnotetext{
${ }^{10}$ http://bexis2.uni-jena.de/
}

augmented by lysimeter installations to monitor the flow of particles, biota, and dissolved materials through the soil and unsaturated zone. Models of water flow in the catchment will be constructed. We will also monitor gas fluxes in the field using newly developed cavity enhanced RAMAN spectroscopy (Keiner et al., 2015). Raman multi-gas analysis enables real-time, continuous, and non-consumptive quantification of the major gases: $\mathrm{N}_{2}, \mathrm{O}_{2}$, and $\mathrm{CO}_{2}$ (Keiner et al., 2015)

To investigate specific mechanisms, rates and controls, mesocosms in the laboratory allow us to measure rates or create extreme events under controlled conditions. Surface mesocosms including plants, herbivores and soils, will be used to investigate the role of changing surface inputs on the fluxes of matter transiting the soils and entering the subsoil. Subsurface mesocosms will track the interactions of fluids, rocks, and biota mimicking conditions in the subsurface.

\section{FIRST RESULTS}

Our two overarching hypotheses were that surface and subsurface were coupled, such that aquifers with recharge in different land uses would differ in their characteristics, and that events at the surface would be detectable in the subsurface. Initial data supports both of these hypotheses, but also highlights the complexities of the processes involved. In this section we will briefly describe some of the collected data and link these to the processes underlying surface-subsurface coupling and how that is affected by events and seasons.

\section{Hydraulic Response of the Aquifer System}

The groundwater system we investigate is relatively shallow, extending from $2 \mathrm{~m}$ below the surface at location $\mathrm{H} 1$ to $40-$ $90 \mathrm{~m}$ below the surface at the footslope location $\mathrm{H} 4$ and $\mathrm{H} 5$. It is partly characterized by large and well-connected conduits characteristic of fractured/karst aquifers. Thus, we expect a rapid and pronounced response of the groundwater table to events. Major recharge events in late winter and early spring can result in rapid (within hours) rise of the groundwater table, sometimes by tens of meters (Figure 7). This response reflects the combined effects of snowmelt and early spring precipitation events with high antecedent soil moisture in winter, reinforced by negligible evapotranspiration of the leafless deciduous beech forest in winter time.

The response of the groundwater table is almost instantaneous in both the HTU and the HTL in the higher elevation portions of the transect with increasing lag times for response in downstream direction. This points to the fact that both aquifer systems are connected to surface near recharge areas with similar recharge characteristics. The fairly rapid decline within a few days to weeks of the groundwater tables to pre-event levels indicates very good connectivity and rapid onset of significant groundwater flow. Such behavior is known for surface near aquifer systems that are affected by karstification (Ford and Williams, 2015).

Response of the hydraulic head is high in early winter with increases of up to $20 \mathrm{~m}$ over a few hours. This is caused by the longer and more effective precipitation events combined with a strong decline in evapotranspiration due to the beginning of the 
TABLE 1 | Measuring program in the Hainich Exploratory.

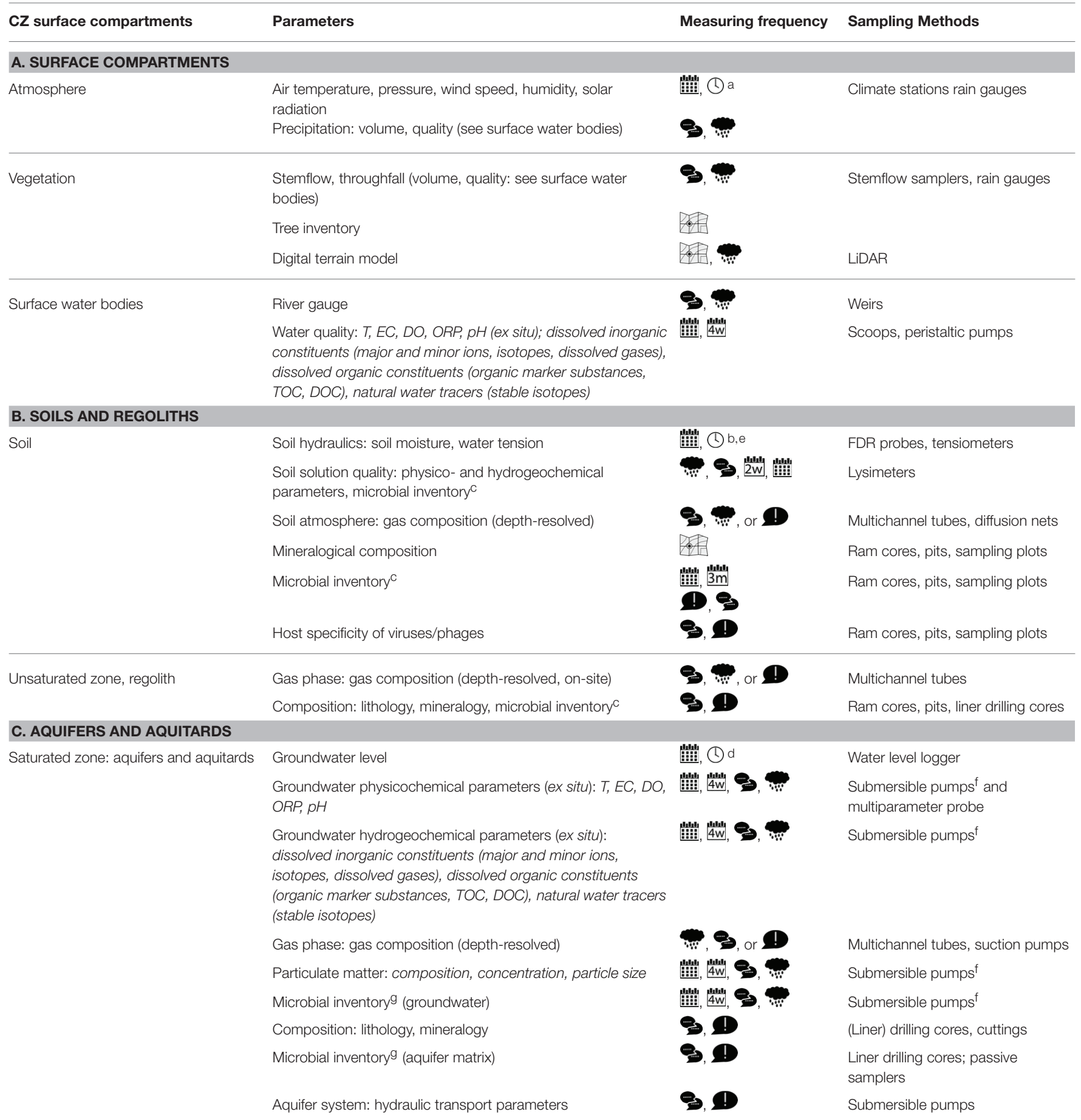

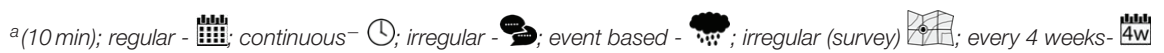

b(10 min);

c microbial inventory: Illumina sequencing bacterial, archaeal 16S rRNA genes, ITS (fungi); RNA- and DNA-based analysis; total microbial abundance, abundance of bacteria, archaea, specific functional guilds (quantitative PCR).

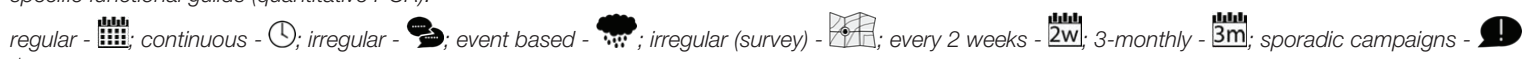
d(10 min);

${ }^{e}(20 \mathrm{~min}) ;$

f(low-flow/high-flow);

Imicrobial inventory: Illumina sequencing bacterial, archaeal 16S rRNA genes, ITS (fungi); RNA- and DNA-based analysis; total microbial abundance, abundance of bacteria, archaea, specific functional guilds (quantitative $P C R$ ).

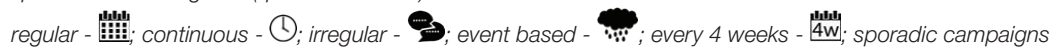




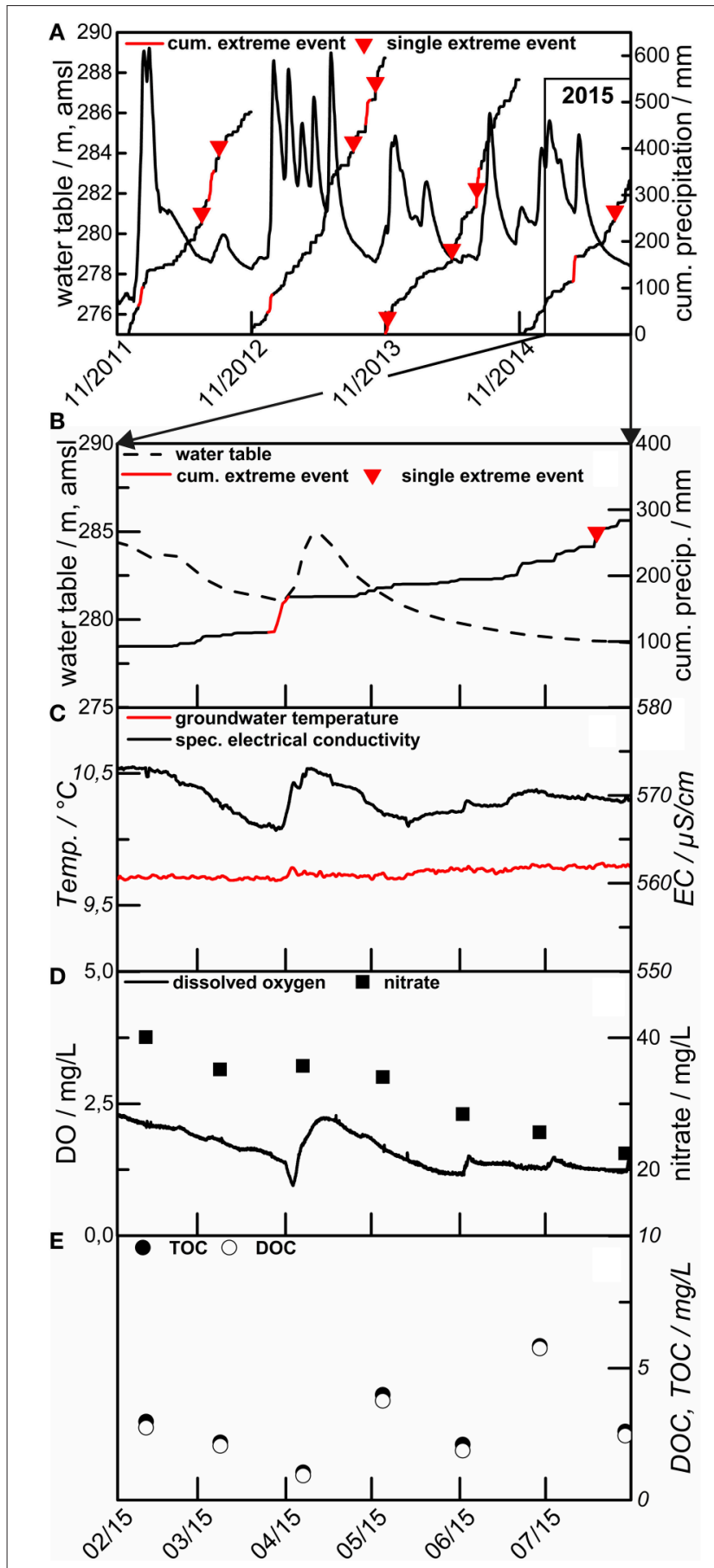

FIGURE 7 | Example hydrograph, precipitation and groundwater level for the years $\mathbf{2 0 1 1}$ to $\mathbf{2 0 1 5}$ (A) at site H3, HTU. Detail of the year 2015, showing water table and precipitation (B), water temperature and el. conductivity (C), dissolved oxygen (DO) and nitrate (D), and total and dissolved organic carbon (TOC/DOC) (E).

vegetation's dormant period. Lag times ranged from a few hours (high flow events, winter season, $\sim 20 \mathrm{~mm}$ /day) up to weeks in the HTU and HTL assemblages, with lag times typically increasing with downstream distance. Relaxation of the groundwater head

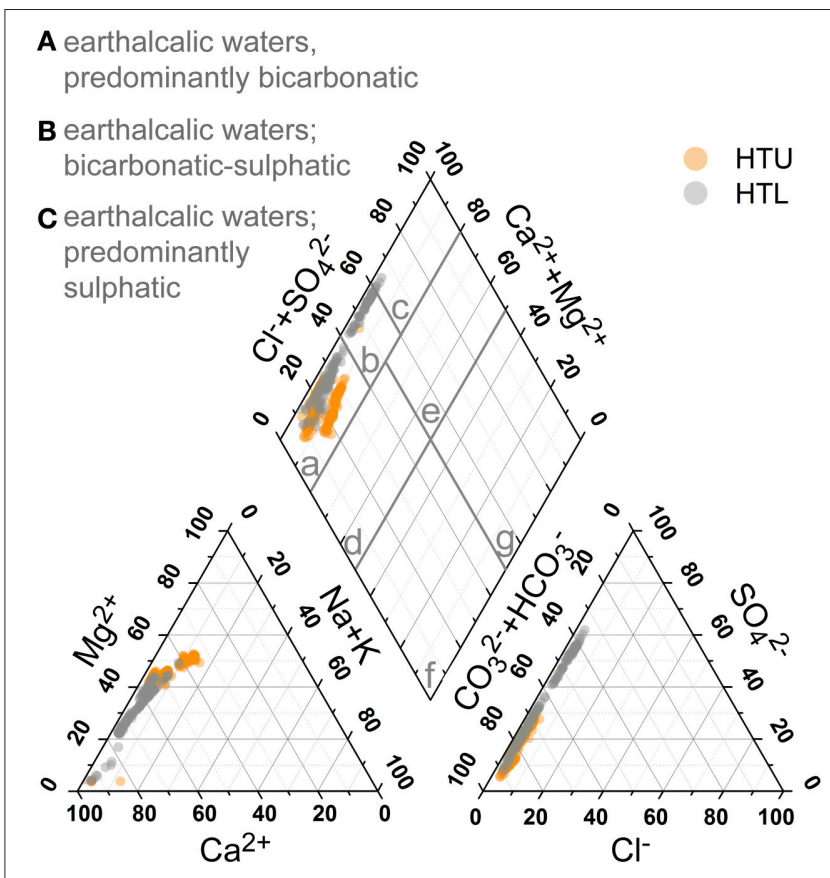

FIGURE 8 | Piper diagram of groundwater samples recorded for more than $\mathbf{4}$ years and all five well locations. Classification after Furtak and Langguth (1967).

following an event typically follows a two phase decline, with a rapid decrease lasting some days to weeks and a slow decline over subsequent months.

A much more interesting observation so far is the fact that-outside of this snowmelt/spring storm period, single precipitation events-classified according the definition used by the world meteorological organization ${ }^{11}$ do not seem to affect the groundwater table and groundwater flow. Both are much more dependent on initial soil moisture conditions and the cumulative precipitation beyond a still-to-be-determined threshold. Most rapid groundwater response is observed with high antecedent soil moisture and the largest cumulative precipitation, while no response is sometimes seen when surface soils are dry.

\section{Hydrogeochemistry}

The $\mathrm{pH}$ of the two aquifers reflects the dominance of limestones, and is above 7.2 with extremes up to 8.0. Electrical conductivity exceeds $500 \mu \mathrm{S} \mathrm{cm}^{-1}$. There are, however, major differences between the biogeochemistry and microbial community composition between the two aquifer assemblages.

Figure 8 gives a general impression on the principal groundwater chemistry. Based on the major anions and cations, the hydrochemistry is dominated by the dissolution of the limestones and marly limestones with dominance of $\mathrm{Ca}^{2+}$ and $\mathrm{Mg}^{2+}$ and $\mathrm{HCO}_{3}^{-}, \mathrm{CO}_{3}^{2-}$ and $\mathrm{SO}_{4}^{2-}$ causing the high alkalinity and hardness of the water. Base cations make up 50-90\% (charge based) of cationic composition of the groundwater. Thus, the HTU and HTL groundwaters are characterized as

\footnotetext{
${ }^{11}$ https://www.wmo.int/pages/index_en.html
} 
earthalkaline bicarbonatic to bicarbonatic-sulfatic waters (Furtak and Langguth, 1967).

Larger differences between the two aquifer assemblages are found in the amount of dissolved oxygen, redox potential, nitrate, and sulfate (Figure 9). In general, the HTL groundwater has higher dissolved oxygen, higher nitrate, higher redoxpotentials than the HTU. With the presumed flow direction, dissolved oxygen decreases in the HTL and HTU aquifers, leading to anoxic conditions in some domains of the aquifer assemblages. We relate these differences to the land uses in the recharge areas and the resulting differences in vegetation cover and soil characteristics-hence, surface characteristics do matter for subsurface biota and their function. The HTL has a direct, short pathway recharge behavior in outcrop or thin covered areas, under forests at the top of the transect, thus allowing oxygen-rich water to infiltrate the aquifer. In contrast, the tiny HTU aquifers have their recharge locations in thicker soils (topsoil and subsoil up to $1 \mathrm{~m}$ ) with presumably smaller direct recharge, and also without tree roots creating potential conduits for macropore flow. Thus, the loess or Keuper overburden and the regolith, including residual clay that must be transited by the seepage water without short-cuts, leaving more time for oxygen consumption and reduction in the redox potential.
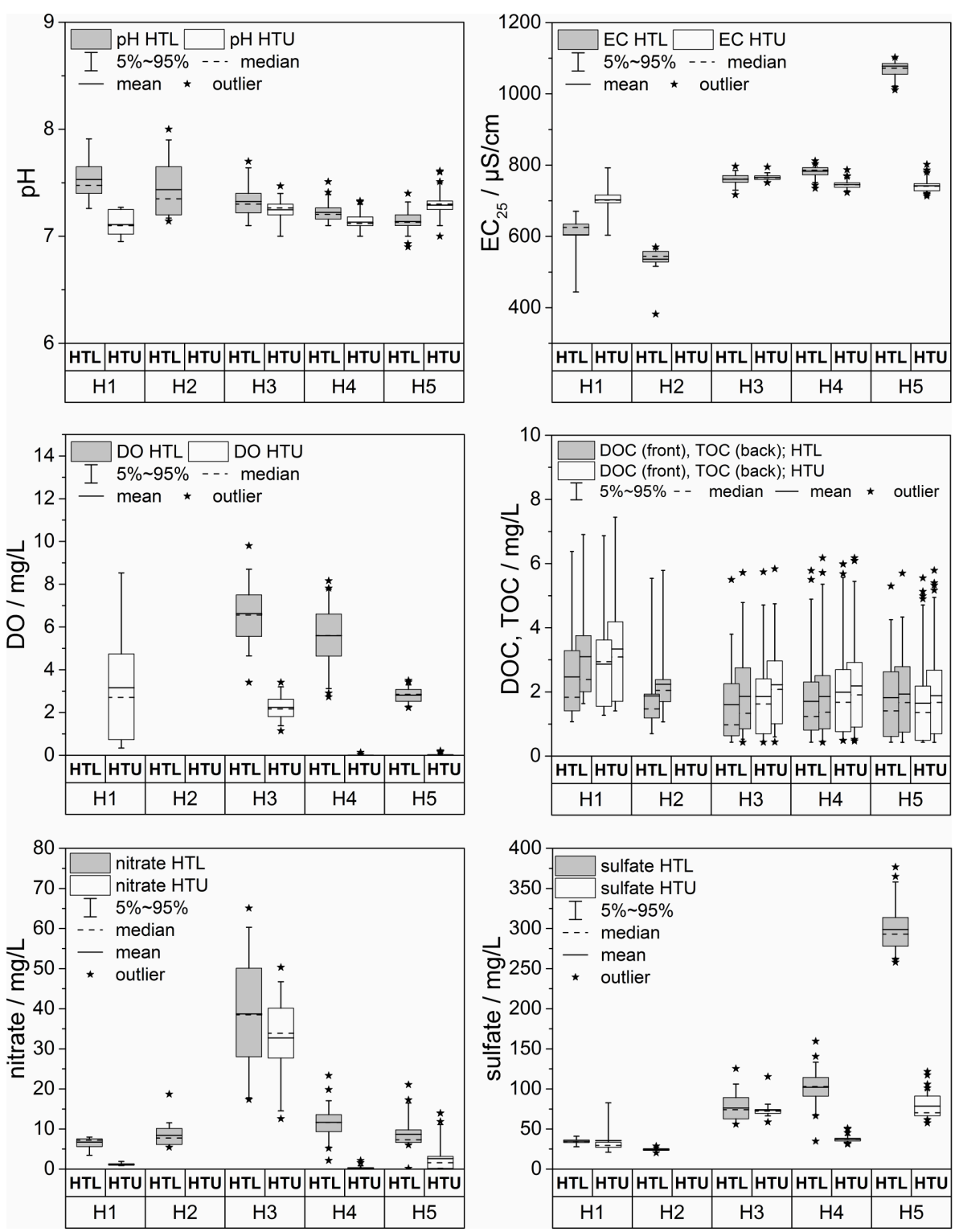

FIGURE 9 | Box-Whisker plots of selected chemical parameters (pH, electrical conductivity, dissolved oxygen (DO), dissolved organic carbon (DOC), total organic carbon (TOC), sulfate and nitrate) sampled at HTL and HTU along the five groundwater sampling sites (H1-H5). Data are based on samples taken during 2013 through 2015. 
The concentrations of total organic C (TOC; which includes both dissolved and particulate organic carbon) are similar for the two aquifer complexes, ranging from 0.5 to $6.0 \mathrm{mg} \mathrm{L}^{-1}$ (TOC) in the HTL and 0.5 to $7.0 \mathrm{mg} \mathrm{L}^{-1}$ (TOC) in the HTU (Figure 9). In general the ratios of TOC/DOC are larger than 1, i.e., there is significant particulate organic C (POC), with selected extremes pointing to the periodic transport of larger particulate $\mathrm{OM}$ fluxes. DOC and TOC show a relative decrease with presumed flow direction in both assemblages. Microbial processes in the different aquifer assemblages may thus be more important than surface inputs in controlling the amount and composition of DOC and TOC with progressively longer flow distances (Opitz et al., 2014).

The impact of surface precipitation events on DOC and TOC are mixed. Concentrations increase with some of the groundwater rise events, though the magnitude of DOC increase is not simply related to the magnitude of the groundwater table excursion (Figure 7). Declines in DOC could represent net consumption, or mixing; ultimately our ability to compare with other parameters (e.g., DO, and isotopes in the DOC and DIC), will help to deconvolve the extent of mixing, recycling, and consumption on subsurface biogeochemical $\mathrm{C}$ cycling.

Differences in DOC and TOC between the two aquifer assemblages (Figure 9) and over time should also be reflected in the molecular characterization of the discharged dissolved organic matter. Shallow forest soils, combined with preferential flow paths could account for relatively lower DOC concentrations in the HTL aquifer that recharges in forest. It has been shown that DOC release in forest subsoils is strongly rate limited and both the concentration and quality of released DOC depend on the residence time under flow conditions (Weigand and Totsche, 1998; Munch et al., 2002). With a thicker overburden more soilborne organic matter reflecting the land use mosaic will reach the groundwater body. The detailed analysis of the molecular composition of DOC as well as the analysis of biomarkers and tracers specific for land use type and even target organisms (plants, animals) will help to elucidate the recharge situation and residence time within the overburden layers (soil, vadose zone), as well as the degree to which organic $\mathrm{C}$ is recycled in the subsurface.

\section{MICROBIAL COMMUNITIES}

Since microbial activities play an important key role in biogeochemical cycles of terrestrial and aquatic environments, one key mission is to gain more insight (i) into the diversity, identity and abundance of microorganisms in the Hainich aquifers including bacteria, archaea, fungi and other eukaryotic microorganisms, (ii) into their metabolic potential and activities, and (iii) into how distribution patterns of microbial communities are linked to physicochemical parameters on both spatial and temporal scales.

The prokaryotic population densities are similar in the target aquifers of the two aquifer assemblages, ranging from $2.7 \times 10^{6}$ to $3.8 \times 10^{8}$ cells $\mathrm{L}^{-1}$ over time (Opitz et al., 2014), which is similar to microbial abundances observed in spring water of alpine karst aquifers (Farnleitner et al., 2005). Quantitative PCR targeting bacterial and archaeal 16S rRNA genes suggested that archaea form a fraction of $0.03-8.2 \%$ of the total microbial population across different transect locations. Protists such as flagellates, ciliates, and amoeba appear to make an important contribution to the control of microbial populations by grazing biofilms in association with rock surfaces within the karstic aquifer system (Risse-Buhl et al., 2013).

Initial investigations have identified two factors which appear to be key drivers of microbial community composition and thus also strongly influence the potential for biogeochemical processes to take place: (i) the strong differences in oxygen availability between the two aquifers, and (ii) the distance to surface soils and thus the likelihood of the input and potential establishment of soil-derived microbial groups in the aquifer microbial communities (Opitz et al., 2014; Herrmann et al., 2015). Comparative investigations of microbial community structure in the groundwater using next generation amplicon sequencing of $16 \mathrm{~S}$ rRNA genes and transcripts revealed that members of the Betaproteobacteria and the CytophagalesFlavobacteria-Bacteroidetes group dominate in the upper, anoxic aquifer while members of the Deltaproteobacteria and Nitrospira dominate the communities in the oxic, lower aquifer (Herrmann et al., 2015). Similarly, members of the Deltaproteobacteria and Nitrospira constituted autochthonous endokarst microbial communities in previous studies of alpine karst aquifers (Pronk et al., 2009).

One way to measure dependence of subsurface on surface conditions is to assess the relative importance of chemolithoautotrophy vs. heterotrophy in aquifer complexes. Molecular surveys targeting $c b b M$ and $c b b L$ genes encoding RubisCO, the key enzyme of the Calvin-Benson-Bassham (CBB) cycle, revealed up to $17 \%$ of the total microbial population in the groundwater has the genetic potential for $\mathrm{CO}_{2}$-fixation via the $\mathrm{CBB}$ cycle, however, without strong differences between the two aquifer complexes (Herrmann et al., 2015). These putative autotrophs are represented by mostly facultative anaerobic microbial groups related to Sulfuricella denitrificans, Sulfuritalea hydrogenivorans, Sideroxydans lithotrophicus ES-1 as well as to members of the genera Thiobacter and Thiobacillus. In addition, sequence analysis pointed to the presence of strictly aerobic ammonia oxidizers known to be autotrophs (Nitrosomonas, Nitrosospira) in the lower aquifer. Overall, our findings point to a strong coupling of autotrophy with the oxidation of reduced sulfur and nitrogen compounds.

\section{MICROBIAL METABOLIC FUNCTIONS AND ACTIVITIES}

In addition to our snap-shot inventories of the groundwater microbial diversity, we follow temporal dynamics of the total and active microbial populations by monthly sampling and by linking community structure to changes in groundwater chemistry or to single events such as snow melt or heavy rain fall. These data can be compared to temporal fluctuations of 
DOC (both quantity and composition) and other dissolved nutrients to better link microbial communities to biogeochemical cycles. We aim to identify key organic carbon compounds and, as inferred by strong positive microbial responses to certain compounds, and key degradation pathways which could shape heterotrophy in these aquifers. Here, the use of metagenomics, metatranscriptomics, and proteomics approaches will allow us to assess the functional potential and expressed activities of the aquifers' microbial population across the whole groundwater transect for selected time points. Building on the information derived from these approaches, key biogeochemical processes in the aquifers driven by microbial activities will be identified.

While we await results for some of the planned analyses, our preliminary results confirm similar hydrological responses, but large differences in geochemistry and community composition for the two aquifer complexes that recharge in areas covered by either forest alone or forest combined with managed grassland/agriculture. Response to events can be seen in both hydrolic head and in geochemistry, but the magnitude of responses clearly depends on antecedent conditions, and will require observation of numerous events to understand. Thus, while we can answer the question in our title and say that surface signals can be found up to $90 \mathrm{~m}$ deep in our groundwater wells in HTL, the processes making this connection vary and in particular respond to precipitation events at the surface.

\section{SUMMARY/OUTLOOK}

Preliminary data demonstrate major differences in the two shallow aquifer assemblages related to land use in their respective recharge areas and indicate long-term coupling of subsurface conditions to the surface. The upper, HTU assemblage has much less $\mathrm{O}_{2}$, and a different microbial community compared to the HTL. Thus, even if transformed, some imprint of surface conditions (forest vs. grassland) is still identifiable in groundwater. Ongoing work attempts to understand the reasons for these differences, especially the degree to which they are traceable to various factors associated with land use (e.g., nutrient additions in grassland) and/or of hydrologic characteristics (e.g., lack of root macropore channels in grassland compared to forest). Tracer experiments are planned to determine water transit time during different hydrological conditions, and we continue to search for specific tracers that can provide markers of surface land use and subsequent signal transformation as dissolved and particulate matter moves through the subsurface. Of particular interest is understanding how organisms and genetic information may be transported through the $\mathrm{CZ}$. We

\section{REFERENCES}

Akob, D. M., and Küsel, K. (2011). Where microorganisms meet rocks in the Earth's Critical Zone. Biogeosciences 8, 3531-3543. doi: 10.5194/bg-8-3531-2011

Alfreider, A., and Vogt, C. (2012). Genetic evidence for bacterial chemolithoautotrophy based on the reductive tricarboxylic acid plan in future to test the hypothesis that transducing phages are important vectors of the vertical flow of genetic information from soils to aquifers by applying specific phages as tracers. In ongoing work, assessment of the in situ viral metagenome will be combined with experiments testing the migration behavior of viral particles in column experiments. In addition to their potential roles as vectors of information flow, the importance of phages for the control of bacterial population densities in aquifer systems has only rarely been addressed (Eydal et al., 2009; Holmes et al., 2015).

We also note that both HTU and HTL aquifer assemblages respond rapidly to hydrologic events, although the effects depend strongly on the size of the event, the antecedent soil moisture conditions and the activity of vegetation in transpiring precipitated water. Explaining the response of water chemistry, for example, TOC and DOC concentrations, to events will likely require multiple years of data collection that covers a range of different forcings and responses. Overall the infrastructure of the Hainich CZE has been demonstrated to be an effective tool for answering our questions about the interactions between biota and the subsurface environment, and ultimately questions about how subsurface conditions reflect surface land use and geologic setting. As a member of the international CZ community, AquaDiva and its infrastructure welcomes collaborators with new questions, ideas and tools to improve our understanding of the role of biota in the Earth's critical zone. Data from AquaDiva will be made available through a dedicated database system.

\section{AUTHOR CONTRIBUTIONS}

KK, KT, ST, RL, CS, and MH substantially contributed to the conception and design of the work as well as the acquisition, analysis and interpretation of data for the work and drafting the work, revising it critically for important intellectual content and approved the version to be published and agree to be accountable for all aspects of the work in ensuring that questions related to the accuracy or integrity of any part of the work are appropriately investigated and resolved. KK, KT, and ST are speakers of the CRC AquaDiva.

\section{ACKNOWLEDGMENTS}

We thank Anna Rusznyak and Anna Spaethe for giving support through the central office. The work has been funded by the state of Thuringia 'ProExzellenz' initiative AquaDiv@Jena (1071) and Deutsche Forschungsgemeinschaft (DFG), Collaborative Research Center (CRC) 1076, AquaDiva. 10.1264/jsme2.ME11274

Alfreider, A., Vogt, C., Hoffmann, D., and Babel, W. (2003). Diversity of ribulose-1,5-bisphosphate carboxylase/oxygenase large-subunit genes from groundwater and aquifer microorganisms. Microb Ecol. 45, 317-328. doi: 10.1007/s00248-003-2004-9 
Amalfitano, S., Del Bon, A., Zoppini, A., Ghergo, S., Fazi, S., Parrone, D., et al. (2014). Groundwater geochemistry and microbial community structure in the aquifer transition from volcanic to alluvial areas. Water Res. 65, 384-394. doi: 10.1016/j.watres.2014.08.004

Andreo, B., Ravbar, N., and Vias, J. M. (2009). Source vulnerability mapping in carbonate (karst) aquifers by extension of the COP method: application to pilot sites. Hydrogeol. J. 17, 749-758. doi: 10.1007/s10040-008-0391-1

Baisden, W. T., Amundson, R., Brenner, D. L., Cook, A. C., Kendall, C., and Harden, J. W. (2002a). A multiisotope C and N modeling analysis of soil organic matter turnover and transport as a function of soil depth in a California annual grassland soil chronosequence. Glob. Biogeochem. Cycle 16, 1135. doi: 10.1029/2001GB001823

Baisden, W. T., Amundson, R., Cook, A. C., and Brenner, D. L. (2002b). Turnover and storage of $\mathrm{C}$ and $\mathrm{N}$ in five density fractions from California annual grassland surface soils. Glob. Biogeochem. Cycle 16, 1117. doi: $10.1029 / 2001 G B 001822$

Baker, M. A., Valett, H. M., and Dahm, C. N. (2000). Organic carbon supply and metabolism in a shallow groundwater ecosystem. Ecology 81, 3133-3148. doi: 10.1890/0012-9658(2000)081[3133:OCSAMI]2.0.CO;2

Basic Research Opportunities in Earth Science (2015). Available online at: http:// www.nap.edu/openbook.php?record_id=9981

BGR (2005). Soil Regions Map of the European Union and Adjacent Countries 1:5,000,000 (Version 2.0). EU catalogue number S.P.I.05.134. Special Publication, Ispra.

BGR and UNESCO (eds.). (2014). International Hydrogeological Map of Europe (IHME1500). (Digital map data v1.1.).

Boetius, A., Ravenschlag, K., Schubert, C. J., Rickert, D., Widdel, F., Gieseke, A., et al. (2000). A marine microbial consortium apparently mediating anaerobic oxidation of methane. Nature 407, 623-626. doi: 10.1038/35036572

Brigmon, R., Martin, H., Morris, T., Bitton, G., and Zam, S. (1994). Biogeochemical ecology of thiothrix spp in underwater limestone caves. Geomicrobiol. J. 12, 141-159. doi: 10.1080/01490459409377982

Culver, D. A., Boucherle, M. M., Bean, D. J., and Fletcher, J. W. (1985). Biomass of freshwater crustacean zooplankton from length-weight regressions. Can. J. Fish Aquat. Sci. 42, 1380-1390. doi: 10.1139/f85-173

D'Hondt, S. (2013). Subsurface sustenance. Nat. Geosci. 6, 426-427. doi: $10.1038 /$ ngeo 1843

Dibbern, D., Schmalwasser, A., Lueders, T., and Totsche, K. U. (2014). Selective transport of plant root-associated bacterial populations in agricultural soils upon snowmelt. Soil Biol. Biochem. 69, 187-196. doi: 10.1016/j.soilbio.2013.10.040

Eisenhauer, N., Dobies, T., Cesarz, S., Hobbie, S. E., Meyer, R. J., Worm, K., et al. (2013). Plant diversity effects on soil food webs are stronger than those of elevated $\mathrm{CO} 2$ and $\mathrm{N}$ deposition in a long-term grassland experiment. Proc. Natl. Acad. Sci. U.S.A. 110, 6889-6894. doi: 10.1073/pnas.12173 82110

Eisenhauer, N., Schlaghamersky, J., Reich, P. B., and Frelich, L. E. (2011). The wave towards a new steady state: effects of earthworm invasion on soil microbial functions. Biol. Invasions. 13, 2191-2196. doi: 10.1007/s10530-0110053-4

Eydal, H. S. C., Jagevall, S., Hermansson, M., and Pedersen, K. (2009). Bacteriophage lytic to Desulfovibrio aespoeensis isolated from deep groundwater. ISME J. 3, 1139-1147. doi: 10.1038/ismej.2009.66

Farnleitner, A. H., Wilhartitz, I., Ryzinska, G., Kirschner, A. K. T., Stadler, H., Burtscher, M. M., et al. (2005). Bacterial dynamics in spring water of alpine karst aquifers indicates the presence of stable autochthonous microbial endokarst communities. Environ. Microbiol. 7, 1248-1259. doi: 10.1111/j.14622920.2005.00810.x

Ford, D., and Williams, P. D. (2015).Wiley: Karst Hydrogeology and Geomorphology-Williams [Internet]. [cited Aug 11]. Available online at: http://eu.wiley.com/WileyCDA/WileyTitle/productCd-0470849967.html

Foulquier, A., Malard, F., Mermillod-Blondin, F., Montuelle, B., Doledec, S., Volat, B., et al. (2011). Surface water linkages regulate trophic interactions in a groundwater food web. Ecosystems 14, 1339-1353. doi: 10.1007/s10021-0119484-0

Foulquier, A., Simon, L., Gilbert, F., Fourel, F., Malard, F., and MermillodBlondin, F. (2010). Relative influences of DOC flux and subterranean fauna on microbial abundance and activity in aquifer sediments: new insights from
13C-tracer experiments. Freshwater Biol. 55, 1560-1576. doi: 10.1111/j.13652427.2010.02385.x

Froberg, M., Kleja, D. B., and Hagedorn, F. (2007). The contribution of fresh litter to dissolved organic carbon leached from a coniferous forest floor. Eur. J. Soil Sci. 58, 108-114. doi: 10.1111/j.1365-2389.2006.00812.x

Furtak, H., and Langguth, H. R. (1967). Zur hydrochemischen kennzeichnung von grundwässern und grundwassertypen mittels kennzahlen. Mem. IAH-congress, 1965. Hannover: International Association of Hydrogeologists.

Gillon, M., Barbecot, F., Gibert, E., Alvarado, J. A. C., Marlin, C., and Massault, M. (2009). Open to closed system transition traced through the TDIC isotopic signature at the aquifer recharge stage, implications for groundwater C-14 dating. Geochim. Cosmochim. Acta 73, 6488-6501. doi: 10.1016/j.gca.2009.07.032

Gillon, M., Barbecot, F., Gibert, E., Plain, C., Corcho-Alvarado, J.-A., and Massault, M. (2012). Controls on C-13 and C-14 variability in soil CO2. Geoderma 189, 431-441. doi: 10.1016/j.geoderma.2012.06.004

Goldscheider, N., Hunkeler, D., and Rossi, P. (2006). Review: Microbial biocenoses in pristine aquifers and an assessment of investigative methods. Hydrogeol. J. 14, 926-941. doi: 10.1007/s10040-005-0009-9

Gray, C. J., and Engel, A. S. (2013). Microbial diversity and impact on carbonate geochemistry across a changing geochemical gradient in a karst aquifer. ISME J. 7, 325-337. doi: 10.1038/ismej.2012.105

Hallbeck, L., and Pedersen, K. (2008). Characterization of microbial processes in deep aquifers of the Fennoscandian Shield. Appl. Geochem. 23, 1796-1819. doi: 10.1016/j.apgeochem.2008.02.012

Han, L.-F., and Plummer, L. N. (2013). Revision of Fontes \& Garnier's model for the initial C-14 content of dissolved inorganic carbon used in groundwater dating. Chem. Geol. 351, 105-114. doi: 10.1016/j.chemgeo.2013.05.011

Herrmann, M., Rusznyak, A., Akob, D. M., Schulze, I., Opitz, S., Totsche, K. U., et al. (2015). Large Fractions of CO2-fixing microorganisms in pristine limestone aquifers appear to be involved in the oxidation of reduced sulfur and nitrogen compounds. Appl. Environ. Microbiol. 81, 2384-2394. doi: 10.1128/AEM.03269-14

Hinrichs, K. U., Hayes, J. M., Sylva, S. P., Brewer, P. G., and DeLong, E. F. (1999). Methane-consuming archaebacteria in marine sediments. Nature 398, 802-805. doi: $10.1038 / 19751$

Hoehler, T. M., and Jorgensen, B. B. (2013). Microbial life under extreme energy limitation. Nat. Rev. Microbiol. 11, 83-94. doi: 10.1038/nrmicro2939

Holden, P. A., and Fierer, N. (2005). Microbial processes in the Vadose Zone. Vadose Zone J. 4, 1-21. doi: 10.2113/4.1.1

Holmes, D. E., Giloteaux, L., Chaurasia, A. K., Williams, K. H., Luef, B., Wilkins, M. J., et al. (2015). Evidence of Geobacter-associated phage in a uraniumcontaminated aquifer. ISME J. 9, 333-346. doi: 10.1038/ismej.2014.128

Jarvis, N. J. (2007). A review of non-equilibrium water flow and solute transport in soil macropores: principles, controlling factors and consequences for water quality. Eur. J. Soil Sci. 58, 523-546. doi: 10.1111/j.1365-2389.2007.00915.x

Jorgensen, B. B., and Boetius, A. (2007). Feast and famine - microbial life in the deep-sea bed. Nat. Rev. Microbiol. 5, 770-781. doi: 10.1038/nrmicro1745

Keiner, R., Herrmann, M., Küsel, K., Popp, J., and Frosch, T. (2015). Rapid monitoring of intermediate states and mass balance of nitrogen during denitrification by means of cavity enhanced Raman multi-gas sensing. Anal. Chim. Acta 864, 39-47. doi: 10.1016/j.aca.2015.02.007

Kellermann, C., Selesi, D., Lee, N., Hügler, M., Esperschütz, J., Hartmann, A., et al. (2012). Microbial CO2 fixation potential in a tar-oil-contaminated porous aquifer. FEMS Microbiol. Ecol. 81, 172-187. doi: 10.1111/j.15746941.2012.01359.x

Kindler, R., Siemens, J., Kaiser, K., Walmsley, D. C., Bernhofer, C., Buchmann, N., et al. (2011). Dissolved carbon leaching from soil is a crucial component of the net ecosystem carbon balance. Glob. Change Biol. 17, 1167-1185. doi: 10.1111/j.1365-2486.2010.02282.x

Knohl, A., Schulze, E.-D., Kolle, O., and Buchmann, N. (2003). Large carbon uptake by an unmanaged 250-year-old deciduous forest in Central Germany. Agric. For. Meteorol. 118, 151-167. doi: 10.1016/S0168-1923(03)00115-1

Kracht, O., and Gleixner, G. (2000). Isotope analysis of pyrolysis products from Sphagnum peat and dissolved organic matter from bog water. Org. Geochem. 31, 645-654. doi: 10.1016/S0146-6380(00)00041-3

Kramer, S., Marhan, S., Ruess, L., Armbruster, W., Butenschoen, O., Haslwimmer, H., et al. (2012). Carbon flow into microbial and fungal biomass as a basis for 
the belowground food web of agroecosystems. Pedobiologia 55, 111-119. doi: 10.1016/j.pedobi.2011.12.001

Kumar, R., Samaniego, L., and Attinger, S. (2010). The effects of spatial discretization and model parameterization on the prediction of extreme runoff characteristics. J. Hydrol. 392, 54-69. doi: 10.1016/j.jhydrol.2010.07.047

Lange, M., Eisenhauer, N., Sierra, C. A., Bessler, H., Engels, C., Griffiths, R. I., et al. (2015). Plant diversity increases soil microbial activity and soil carbon storage. Nat. Commun. 6:6707. doi: 10.1038/ncomms7707

Lehman, R. M., Colwell, F. S., and Bala, G. A. (2001). Attached and unattached microbial communities in a simulated basalt aquifer under fractureand porous-flow conditions. Appl. Environ. Microbiol. 67, 2799-2809. doi: 10.1128/AEM.67.6.2799-2809.2001

le Mellec, A., and Michalzik, B. (2008). Impact of a pine lappet (Dendrolimus pini) mass outbreak on $\mathrm{C}$ and $\mathrm{N}$ fluxes to the forest floor and soil microbial properties in a Scots pine forest in Germany. Can. J. For. Res. 38, 1829-1841. doi: 10.1139/X08-045

Lin, L.-H., Wang, P.-L., Rumble, D., Lippmann-Pipke, J., Boice, E., Pratt, L. M., et al. (2006). Long-term sustainability of a high-energy, low-diversity crustal biome. Science 314, 479-482. doi: 10.1126/science.1127376

Loreau, M., Naeem, S., and Inchausti, P. (2002). Biodiversity and Ecosystem Functioning: Synthesis and Perspectives. New York, NY: Oxford University Press.

McCollom, T. M., and Seewald, J. S. (2013). Serpentinites, hydrogen, and life. Elements 9, 129-134. doi: 10.2113/gselements.9.2.129

McMahon, S., and Parnell, J. (2014). Weighing the deep continental biosphere. FEMS Microbiol. Ecol. 87, 113-120. doi: 10.1111/1574-6941.12196

Michaelis, W., Seifert, R., Nauhaus, K., Treude, T., Thiel, V., Blumenberg, M., et al. (2002). Microbial reefs in the Black Sea fueled by anaerobic oxidation of methane. Science 297, 1013-1015. doi: 10.1126/science.1072502

Michalzik, B. (2011). "Insects, Infestations, and Nutrient Fluxes," in Forest Hydrology and Biogeochemistry, eds D. F. Levia, D. Carlyle-Moses, and T. Tanaka (Netherlands: Springer), 557-80. (Ecological Studies).

Miltner, A., Richnow, H. H., Kopinke, F. D., and Kastner, M. (2004). Assimilation of $\mathrm{CO} 2$ by soil microorganisms and transformation into soil organic matter. Org Geochem. 35, 1015-1024. doi: 10.1016/j.orggeochem.2004.05.001

Miltner, A., Richnow, H. H., Kopinke, F. D., and Kastner, M. (2005). Incorporation of carbon originating from $\mathrm{CO} 2$ into different compounds of soil microbial biomass and soil organic matter. Isot Environ. Health Stud. 41, 135-140. doi: $10.1080 / 10256010412331314265$

Munch, J. M., Totsche, K. U., and Kaiser, K. (2002). Physicochemical factors controlling the release of dissolved organic carbon from columns of forest subsoils. Eur. J. Soil Sci. 53, 311-320. doi: 10.1046/j.1365-2389.2002. 00439.x

Noronha, A. L., Johnson, K. R., Hu, C., Ruan, J., Southon, J. R., and Ferguson, J. E. (2014). Assessing influences on speleothem dead carbon variability over the Holocene: Implications for speleothem-based radiocarbon calibration. Earth Planet Sci. Lett. 394, 20-29. doi: 10.1016/j.epsl.2014.03.015

Opitz, S., Küsel, K., Spott, O., Totsche, K. U., and Herrmann, M. (2014). Oxygen availability and distance to surface environments determine community composition and abundance of ammonia-oxidizing prokaroytes in two superimposed pristine limestone aquifers in the Hainich region, Germany. FEMS Microbiol. Ecol. 90, 39-53. doi: 10.1111/1574-6941.12370

Pan, D., Watson, R., Wang, D., Tan, Z. H., Snow, D. D., and Weber, K. A. (2014). Correlation between viral production and carbon mineralization under nitrate-reducing conditions in aquifer sediment. ISME J. 8, 1691-1703. doi: 10.1038/ismej.2014.38

Pedersen, K. (1997). Microbial life in deep granitic rock. FEMS Microbiol. Rev. 20, 399-414. doi: 10.1111/j.1574-6976.1997.tb00325.x

Pedersen, K., and Ekendahl, S. (1992a). Incorporation of Co2 and introduced organic-compounds by bacterial-populations in groundwater from the deep crystalline bedrock. J. Gen. Microbiol. 138, 369-376. doi: 10.1099/00221287138-2-369

Pedersen, K., and Ekendahl, S. (1992b). Assimilation of Co2 and introduced organic-compounds by bacterial communities in groundwater from southeastern sweden deep crystalline bedrock. Microb Ecol. 23, 1-14. doi: 10.1007/BF00165903

Perrette, Y., Poulenard, J., Protiere, M., Fanget, B., Lombard, C., Miege, C., et al. (2015). Determining soil sources by organic matter EPR fingerprints in two modern speleothems. Org. Geochem. 88, 59-68. doi: 10.1016/j.orggeochem.2015.08.005

Praamsma, T., Novakowski, K., Kyser, K., and Hall, K. (2009). Using stable isotopes and hydraulic head data to investigate groundwater recharge and discharge in a fractured rock aquifer. J. Hydrol. 366, 35-45. doi: 10.1016/j.jhydrol.2008. 12.011

Prokushkin, A. S., Gleixner, G., McDowell, W. H., Ruehlow, S., and Schulze, E.-D. (2007). Source- and substrate-specific export of dissolved organic matter from permafrost-dominated forested watershed in central Siberia. Glob. Biogeochem. Cycle 21, GB4003. doi: 10.1029/2007GB002938

Pronk, M., Goldscheider, N., and Zopfi, J. (2008). Microbial communities in karst groundwater and their potential use for biomonitoring. Hydrogeol. J. 17, 37-48. doi: $10.1007 / \mathrm{s} 10040-008-0350-\mathrm{x}$

Pronk, M., Goldscheider, N., Zopfi, J., and Zwahlen, F. (2009). Percolation and particle transport in the unsaturated zone of a karst aquifer. Ground Water 47 , 361-369. doi: 10.1111/j.1745-6584.2008.00509.x

Proulx, R., and Fahrig, L. (2010). Detecting human-driven deviations from trajectories in landscape composition and configuration. Landsc. Ecol. 25, 1479-1487. doi: 10.1007/s10980-010-9523-9

Richter, D. D., Markewitz, D., Trumbore, S. E., and Wells, C. G. (1999). Rapid accumulation and turnover of soil carbon in a re-establishing forest. Nature 400, 56-58. doi: 10.1038/21867

Richter D. d. Jr., and Mobley, M. L. (2009). Environment. monitoring earth's critical zone. Science 326, 1067-1068. doi: 10.1126/science.1179117

Risse-Buhl, U., Herrmann, M., Lange, P., Akob, D. M., Pizani, N., Schoenborn, W., et al. (2013). Phagotrophic protist diversity in the groundwater of a karstified aquifer - morphological and molecular analysis. J. Eukaryot Microbiol. 60, 467-479. doi: 10.1111/jeu.12054

Schiperski, F., Zirlewagen, J., Hillebrand, O., Licha, T., and Scheytt, T. (2015). Preliminary results on the dynamics of particles and their size distribution at a karst spring during a snowmelt event. J. Hydrol. 524, 326-332. doi: 10.1016/j.jhydrol.2015.02.035

Shabarova, T., Widmer, F., and Pernthaler, J. (2013). Mass effects meet species sorting: transformations of microbial assemblages in epiphreatic subsurface karst water pools. Environ. Microbiol. 15, 2476-2488. doi: 10.1111/14622920.12124

Sherwood Lollar, B., Voglesonger, K., Lin, L.-H., Lacrampe-Couloume, G., Telling, J., Abrajano, T. A., et al. (2007). Hydrogeologic controls on episodic H2 release from precambrian fractured rocks-energy for deep subsurface life on earth and mars. Astrobiology 7, 971-986. doi: 10.1089/ast.2006.0096

Stadler, B., and Michalzik, B. (2000). Effects of phytophagous insects on microorganisms and throughfall chemistry in forested ecosystems: herbivores as switches for the nutrient dynamics in the canopy. Basic Appl. Ecol. 1, 109-116. doi: 10.1078/1439-1791-00016

Stan, J. T. V., Lewis, E. S., Hildebrandt, A., Rebmann, C., and Friesen, J. (2015). Impact of interacting bark structure and rainfall conditions on stemflow variability in a temperate beech-oak forest, central Germany. Hydrol. Sci. J. doi: 10.1080/02626667.2015.1083104. [Epub ahead of print].

Steinbeiss, S., Bessler, H., Engels, C., Temperton, V. M., Buchmann, N., Roscher, C., et al. (2008). Plant diversity positively affects short-term soil carbon storage in experimental grasslands. Glob. Change Biol. 14, 2937-2949. doi: 10.1111/j.13652486.2008.01697.x

Szewzyk, U., Szewzyk, R., and Stenstrom, T. (1994). Thermophilic, anaerobicbacteria isolated from a deep borehole in granite in Sweden. Proc. Natl. Acad. Sci. U.S.A. 91, 1810-1813. doi: 10.1073/pnas.91.5.1810

Taniguchi, M., Tsujimura, M., and Tanaka, T. (1996). Significance of stemflow in groundwater recharge.1. Evaluation of the stemflow contribution to recharge using a mass balance approach. Hydrol. Process. 10, 71-80.

Tiago, I., and Verissimo, A. (2013). Microbial and functional diversity of a subterrestrial high $\mathrm{pH}$ groundwater associated to serpentinization. Environ. Microbiol. 15, 1687-1706. doi: 10.1111/1462-2920.12034

Totsche, K. U., Jann, S., and Koegel-Knabner, I. (2007). Single event-driven export of polycyclic aromatic hydrocarbons and suspended matter from coal tar-contaminated soil. Vadose Zone J. 6, 233-243. doi: 10.2136/vzj2006.0083

Totsche, K. U., Rennert, T., Gerzabek, M. H., Koegel-Knabner, I., Smalla, K., Spiteller, M., et al. (2010). Biogeochemical interfaces in soil: The interdisciplinary challenge for soil science. J. Plant Nutr. Soil Sci. 173, 88-99. doi: 10.1002/jpln.200900105 
Trumbore, S., Davidson, E., Decamargo, P., Nepstad, D., and Martinelli, L. (1995). Belowground cycling of carbon in forests and pastures of Eastern Amazonia. Glob. Biogeochem. Cycle 9, 515-528. doi: 10.1029/95GB02148

Vias, J., Andreo, B., Ravbar, N., and Hoetzl, H. (2010). Mapping the vulnerability of groundwater to the contamination of four carbonate aquifers in Europe. J. Environ. Manage. 91, 1500-1510. doi: 10.1016/j.jenvman.2010. 02.025

Weigand, H., and Totsche, K. U. (1998). Flow and reactivity effects on dissolved organic matter transport in soil columns. Soil Sci. Soc. Am. J. 62, 1268-1274. doi: 10.2136/sssaj1998.03615995006200050017x

Winderl, C., Anneser, B., Griebler, C., Meckenstock, R. U., and Lueders, T. (2008). Depth-resolved quantification of anaerobic toluene degraders and aquifer microbial community patterns in distinct redox zones of a tar oil contaminant plume. Appl. Environ. Microbiol. 74, 792-801. doi: 10.1128/AEM.01951-07

Young, I. M., and Crawford, J. W. (2004). Interactions and self-organization in the soil-microbe complex. Science 304, 1634-1637. doi: 10.1126/science.1097394
Zwahlen, F. (ed.). (2004). COST Action 620: Vulnerability and Risk Mapping for the Protection of Carbonate (karst) Aquifers: Final Report. Luxembourg: Office for Official Publications of the European Communities $297 \mathrm{p}$. (EUR Environment).

Conflict of Interest Statement: The authors declare that the research was conducted in the absence of any commercial or financial relationships that could be construed as a potential conflict of interest.

Copyright (๑) 2016 Küsel, Totsche, Trumbore, Lehmann, Steinhäuser and Herrmann. This is an open-access article distributed under the terms of the Creative Commons Attribution License (CC BY). The use, distribution or reproduction in other forums is permitted, provided the original author(s) or licensor are credited and that the original publication in this journal is cited, in accordance with accepted academic practice. No use, distribution or reproduction is permitted which does not comply with these terms. 